\title{
Optimization in Decision Making in Infrastructure Asset Management: A Review
}

\author{
Lin Chen * and Qiang Bai \\ School of Highway, Chang'an University, Xi'an 710064, China; baiqiang@outlook.com \\ * Correspondence: linchen@chd.edu.cn
}

Received: 12 January 2019; Accepted: 19 March 2019; Published: 1 April 2019

Featured Application: Infrastructure Asset Management is an important and popular research area, especially when the infrastructure networks are expending so quickly. Researchers developed a large number of optimization methods for its decision-making process. While they mainly focus on the individual algorithms and problems, a comprehensive knowledge, given the broad range of optimization methods, is hardly discussed and an analysis and graphical presentation of existing knowledge is necessary. This review is to discuss the current achievements on this subject, share the knowledge, avoid the repeated work, and guide the future research.

\begin{abstract}
Infrastructure assets, serving everyone's daily life, are an essential foundation of any society. Their management faces a wide range of challenges. Hence optimization methods are increasingly applied to assist making management decisions in infrastructure asset management (IAM). A large number of articles apply a broad range of optimization methods in their decision making (DM) and achieve great results. However, they mainly focus on individual methods and a comprehensive knowledge, given the broad range of optimization methods, is hardly discussed. Hence it is valuable to analyze and graphically present the existing knowledge on this subject. This paper, based on a total of 337 articles, provides an overall review of the applications of optimization when making management decisions in IAM, with the intension of enhancing the optimization application and method selection and guiding the future research in this field. More specifically, this paper introduces the application process of optimization when assisting DM in IAM, summarizes the previous application research, and discusses the popular optimization methods applied in DM in IAM. According to the literature review, this paper confirms optimization can effectively assist DM in IAM and a wide range of optimization methods are applicable to assist a variety of DM problems. The recommendations on the applications and selection of optimization methods in the context of IAM are also made to facilitate the applications.
\end{abstract}

Keywords: decision making; infrastructure asset management; optimization

\section{Introduction}

Infrastructure assets, including roads, bridges, pipelines, etc., are essential foundations for any country. They provide services that are necessary for everyone's daily life. However, they are highly capital intensive and sufficient investment is not always made [1,2].

Infrastructure asset management (IAM), also named asset management, is proposed to efficiently manage the infrastructure assets. Because of its broad coverage, IAM has diverse definitions with different focuses [3]. For example, New Zealand Asset Management Support (NAMS) defines IAM as "systematic and coordinated activities and practices of an organization to optimally and sustainably deliver on its objectives through the cost-effective life cycle management of assets" [4]. 
The Federal Highway Administration (FHWA) in the USA defines IAM as a business process that "incorporates the economic assessment of trade-offs among alternative investment options" and therefore makes "cost-effective investment decisions" [5]. Austroads, from Australia, defines IAM as "a systematic process of effectively maintaining, upgrading and operating assets" considering engineering principles, business, and economy in order to deliver optimal community benefits [6]. In general, it arranges management interventions e.g., maintenance and rehabilitation (M\&R), update, etc., to an infrastructure project or an infrastructure network so that the project or the entire network is able to provide the required level of service, subject to the management requirements, e.g., maintenance budget.

Decision making (DM) is an essential part of IAM, which determines the management plan of interventions for the infrastructure asset project or the network. When generating different management plans, i.e., implementing different interventions to different network segments at different points of time, the management outcomes, e.g., management cost and infrastructure asset condition, are different. DM is required to find an appropriate management plan so that its outcomes satisfy the goals and requirements of IAM.

However, in modern society, DM is not easy as it faces a wide range of challenges, including large infrastructure asset networks, limited resources, various outcomes, conflicting goals, and uncertainties $[7,8]$. Hence, optimization is applied, and in more recent years, has become popular in DM. A large body of articles applies a broad range of optimization methods to a variety of DM problems. Firstly, the majority of these articles focus on the applications and improvements of individual methods in the context of a certain type of DM and a comprehensive knowledge, given the broad range of optimization methods, is hardly discussed. Secondly, with a growth of publications, it is valuable to analyze and graphically present the existing knowledge on this subject.

This paper aims at enhancing the knowledge of optimization methods and their applications when making management decision in IAM. Its main focuses are below as follows:

- Clarifying optimization methods and their abilities when dealing with DM problems in IAM;

- Summarizing and discussing the previous applications of optimization in DM in IAM, based on a total of 337 articles;

- Specifying the popular optimization methods applied in DM in IAM and making recommendations on their applications.

\section{Background}

DM attempts to find an appropriate management plan for a project or a network of infrastructure assets by assigning proper interventions to the project or the network segments during the analyzed period so that the management outcomes of the project, or the entire network, satisfy the goals and requirements of IAM. While the philosophy of DM may sound easy, it faces many challenges, including the following: A large number of alternative management interventions/strategies, especially at the network level and for long-term analysis, limited investments and resources, various outcomes with unclear relationship, conflicting goals, e.g., low management cost and good infrastructure condition, and risks originating from the uncertainties when planning the future.

As a consequence of the challenges, optimization is increasingly applied to assist DM. Optimization is a discipline of Operations Research, which applies scientific methods to "conduct and coordinate the operations" for DM problems [9]. Taking advantage of mathematical analysis, optimization has great strengths and high potentials to assist DM in IAM, as follows:

- With the help of powerful computers, optimization deals with large data, i.e., a large number of segments and alternative strategies/management interventions, so large networks and life-cycle analysis can be handled. 
- Based on well-designed algorithms, optimization is able to find solutions for hard problems, e.g., allocating limited budget to a large network, and therefore promotes the best use of available resources.

- Optimization covers a variety of variables and formulae to describe different management outcomes and examines possible trade-offs accordingly.

- Optimization can involve multiple objectives, even the conflicting ones. The compromise of the conflicting goals is not necessary during the optimization.

- Optimization can also consider uncertainties with fuzzy variables, and can therefore help with estimating the uncertainties and controlling the risks during the management period.

A broad range of optimization methods have been introduced in DM in IAM. Even though the algorithms are different, their application process is similar when dealing with DM problems. Optimization methods cannot be directly applied to a practical problem and a mathematical description of the practical problem is needed, which is the so-called optimization model. Management outcomes are represented by variables and outcome relationships are described by formulae. One or several main management goals are defined as the optimization objective(s) and other goals and management requirements are defined as optimization constraints. Both objectives and constraints are formulated with related variables. Then, an optimization method is applied to solve the formulated optimization problem. A proper optimization method can effectively analyze an optimization problem, quickly generate high-quality solutions, and, therefore, better facilitates the management decisions in IAM [10].

After the optimization, a solution or a set of solutions are generated to help decision makers to understand their problems and make an appropriate management plan. The good solution(s) can offer accurate and reliable information about the addressed problem, while the poor solution(s) may lead to a wrong direction. Hence, it is important to select a proper optimization method that generates high quality solution(s) for a specific DM problem. However, a broad range of optimization methods are applicable in this field, each with different characteristics and application scope. Without a comprehensive understanding of these methods, the method selection can be hard.

\section{Review of the Applications of Optimization Methods in Decision Making in Infrastructure Asset Management}

To date, optimization methods are increasingly applied to assist DM and great achievements are obtained. However, a comprehensive knowledge, given the broad range of optimization methods in the context of DM in IAM, is still missing. In this section, a total of 337 articles, that apply optimization methods in this field, are reviewed. These articles, mainly journal papers and conference proceedings, were obtained from main literature databases with key subject words Infrastructure Management, Infrastructure Asset Management, Pavement Management, and Decision Making. They are listed in Appendix A. The following sections summarize these articles and discuss their applications.

\subsection{Application History}

As a terminology, IAM may sound new but, according to Sharma [11], it has a history of around three hundred years and has been employed by U.S. utilities for a long time. One of the earliest attempts was made in 1975 by Abelson and Flowerdew, who used dynamic programming to determine the least required to maintain a road project in Jamaica over 10 years [12]. Then, more optimization methods were introduced in this field. In the 1980s, the Arizona Department of Transportation officially implemented an optimization method in their pavement M\&R system, the "Network Optimization System" [13]. In the 1990s, the subject of managing infrastructure assets expended from management systems of a single object to a broader orientation [14]. In the late 1990s, the idea of IAM was adopted in the USA to assist the management of infrastructure assets [15]. To efficiently manage infrastructure asset networks, the American Federal Highway Administration (FHWA) established the Office of Asset Management in 1999 and encouraged all state departments of transportation to apply rational methods when managing their infrastructure assets [16]. 
Figure 1 demonstrates the reviewed articles published by decades. It shows there is a jump in the 1990s and a big increase in the 2000s. The increase in the number of articles continues in the 2010s. Two reasons contribute to this increase, as follows: (1) IAM develops rapidly and their DM becomes too hard to be easily analyzed by conventional non-optimization methods and (2) optimization is developing and more optimization methods are applicable to DM in IAM. The authors need to point out that the number of articles the last decade of Figure 1 is not a complete summary, as the decade of 2010-2019 is not completed.

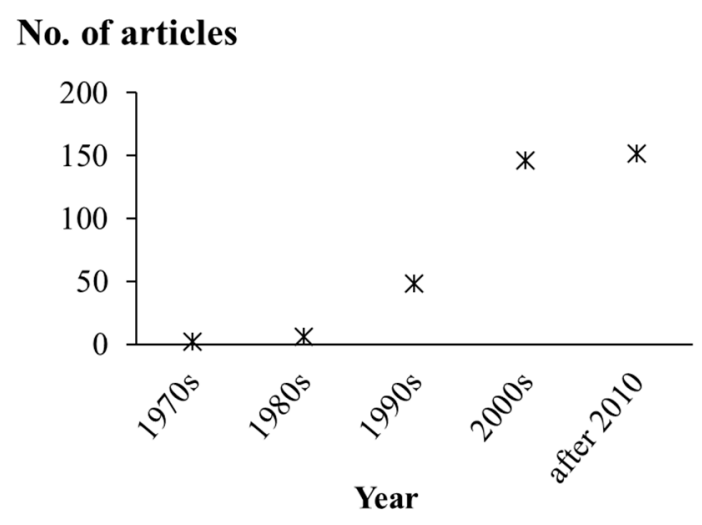

Figure 1. Number of articles published in decades.

Now optimization has become a fashion in IAM and not only the in academic world. Commercial companies also put large effort into to developing IAM software tools based on optimization. Many well-designed commercial software tools, including dTIMS [17], alden [18], TappetBox [19], and Confirm [20], are developed to assist IAM in the real world.

\subsection{Levels of Decision Making}

There are the following two levels of DM: Project- and network- level. The project-level DM only analyzes one infrastructure management project or considers an infrastructure network as a whole and only one management plan or strategy is generated for the project or the entire network. The network-level DM focuses on the segments of an infrastructure network and generates a management strategy for each segment of the network. In general, project-level DM only has a single object, while network-level DM has multiple objects. Figure 2 presents the number of articles published, in decades, focusing on the levels of DMs.

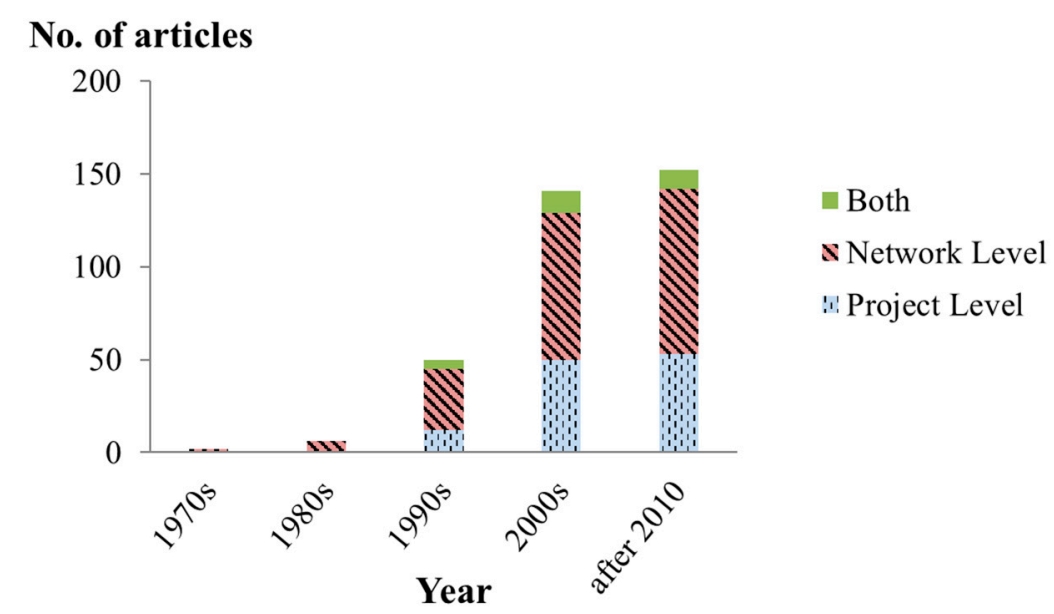

Figure 2. Levels of decision making. 
As shown in Figure 2, among the reviewed articles, the majority of them study network-level decision making, while considerable amount of them are at the project level. Some articles consider both levels in their DM. The numbers of both project- and network- level DM are increasing with the growth of research interests in this field, though the network-level DM has a faster speed. It is important to notice that the discussion on M\&R management is a dominating subject among the reviewed articles and most of the recent articles focus on the network-level DM, while the research on other management, e.g., update, often use the project-level DM. In terms of M\&R management, project-level DM is often used to analyze a special project when the infrastructure, e.g., a bridge, is very important, when a complex model is established, or when complicated outcomes are analyzed [21-23]. Network-level DM considers not only the entire network but also analyzes the individual segments. It produces a management plan/strategy for each segment through the analyzed period so that the whole network can satisfy its management goal and requirements. It is more helpful when managing a network of infrastructure [24,25].

\subsection{Types of Optimization}

Optimization can be generally classified into two types, as follows: Single-objective optimization (SOO) and multi-objective optimization (MOO) [9]. Their relationship and targeted solutions are shown in Figure 3.

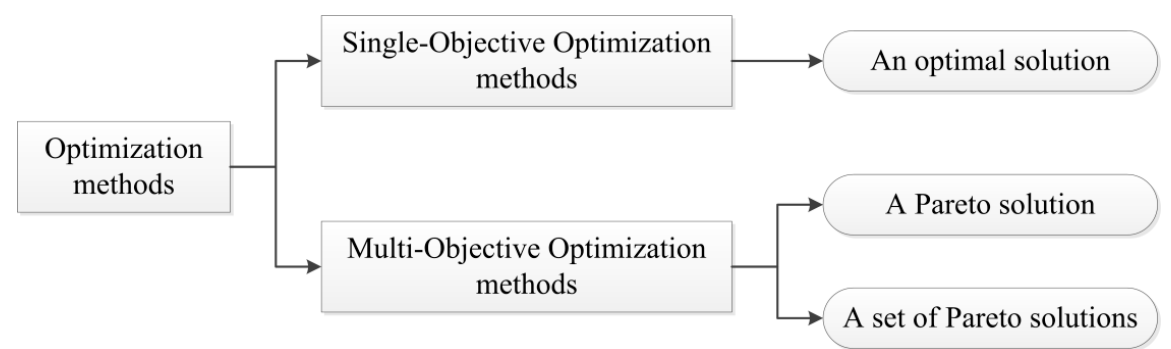

Figure 3. Types of optimization methods and their targeted solutions.

SOO optimizes only one optimization objective subject to optimization constraints. It aims at the optimal solution that produces the best value on the objective and satisfies all the constraints.

MOO optimizes multiple optimization objectives subject to optimization constraints. It aims at Pareto solutions, each producing the best objective values that cannot be improved without worsening the value of another objective. Additionally, all the Pareto solutions satisfy all the constraints. A MOO problem often has more than one existing Pareto solution. Some MOO methods can identify a set of Pareto solutions, while others only identify one Pareto solution, based on the decision makers' preference.

Figure 4 presents the application number of $\mathrm{SOO}$ and $\mathrm{MOO}$ on this subject. According to this figure, SOO was applied first and dominated in this field before the 2010s. Often a main management goal is defined as optimization objective and other goals and requirements are converted to optimization constraints. The commonly used SOO model is to minimize the M\&R cost subject to the acceptable worst condition [26-28] or to improve the condition/condition-based benefit, subject to an annual budget [29-31]. By reviewing the articles, this paper finds out that, today, a considerable amount of articles still use SOO for their DM in IAM, while its orientation is moving to the hard DM problems, including huge networks [32,33], life-cycle analysis [34-36], complex non-linear models [37-39], and cross-assets [40,41]. 


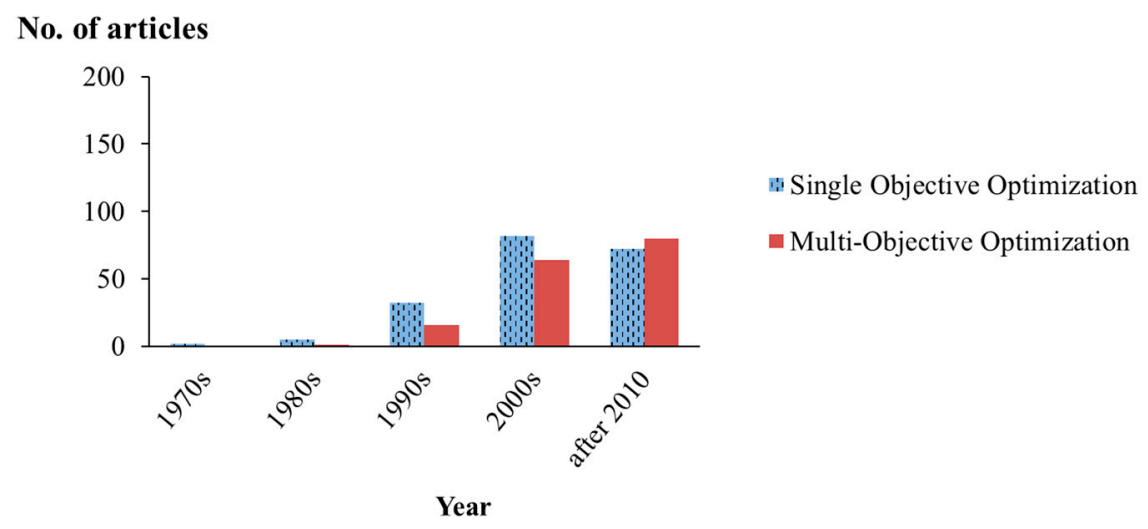

Figure 4. Types of optimization.

With the development of IAM, DM tends to consider multiple goals. When managing infrastructure, some management goals are commensurable and concordant, e.g., improving the network condition and increasing the level of service, and are often integrated into one objective and solved by $\mathrm{SOO}$ algorithms [42-44]. In this case, only one solution is obtained according to the integrated objective. However, often the management goals are incommensurable or conflicting, e.g., improving network condition and reducing management cost [45]. In this case the objectives cannot be simply integrated and this DM is formulated as a MOO problem and each incommensurable or conflicting goal is defined as an individual objective. MOO can describe practical problems in a more rational manner and leads to more informed decisions [7]. Hence, as shown in Figure 4, the application of $\mathrm{MOO}$ is increasing.

A MOO problem often has a set of existing Pareto solutions. However, not all of the optimization methods can obtain all the existing Pareto solutions. Figure 5 illustrates the percentage of the reviewed articles targeting at one Pareto solution or a set of Pareto solutions when adopting MOO in DM in IAM.

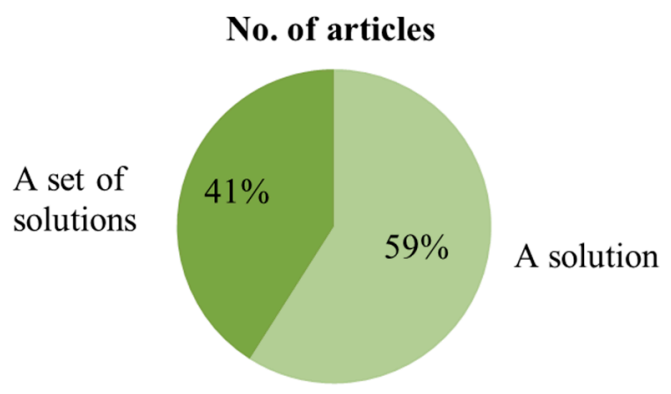

Figure 5. Number of articles targeting at different solution numbers for MOO.

Among the 337 reviewed articles that adopted MOO in their DM in IAM, 59\% of them only produced one solution. These types of solutions require the input from decision makers, i.e., the preference on objectives, weighting of outcomes, expert experience, or practical consideration, and then, one solution is generated to match the decision makers' input. When decision makers have sufficient knowledge to give the input, obtaining one solution can largely simplify the solving procedure and speed up the optimization process.

In recent years, the attempt at a set of Pareto solutions is growing, according to the reviewed articles. This is mainly because the Pareto solution set not only offers the best solutions but also indicates the achievable best objective values, alternative trade-offs of objectives, and objective relationships, which can be used to clarify the problems at hand, balance the objectives, and lead to an informed decision [46-48]. Another interesting point found by the review is, even though MOO can analyze many objectives, $78 \%$ of the reviewed articles adopting MOO only define 2-3 objectives when making the management decisions. When more-than-three objectives are defined, the researchers 
hardly generate a set of Pareto solutions but produce one solution based on specific preference or considerations [49-51]. The main reasons behind this include, (1) when more objectives are optimized, the generation of a whole solution set gets harder and (2) even if a set of solutions are generated, the solution interpretation can be complicated, as each solution corresponds to several objectives.

\subsection{Applied Optimization Methods}

Even as a broad range of optimization methods exist, they are generally divided into the following three classes: Deterministic methods, heuristics, and other methods and software. Deterministic methods are described by Moteleb as the "empirical or mechanic" algorithms that solve optimization problems based on the mathematical theorems and corollaries [52]. Heuristics are described by Silver et al. as "intuitive approaches", where an optimization problem is "interpreted and exploited intelligently to obtain reasonable solution[s]" [53]. Often, heuristics arise from the idea of relatively simple common sense and iteratively reproduce solutions based on identified ones [54]. With the exception of deterministic methods and heuristics, other methods are also proposed by hybridizing existing methods or ideas. Software is also developed based on specific algorithms. The commercial software tools often do not disclose the details of their algorithms or they may involve several algorithms. Hence, it is hard to simply classify these software tools into deterministic methods or heuristics. In this paper, these methods and software tools are classified into the third class while, if the software has a clearly introduced algorithm, its algorithm is classified into the deterministic method or the heuristic.

Figure 6 is a summary of the applied optimization methods. According to this figure, $44 \%$ of the reviewed articles use deterministic methods to help with their DM, followed by heuristics with a percentage of $35 \%$.

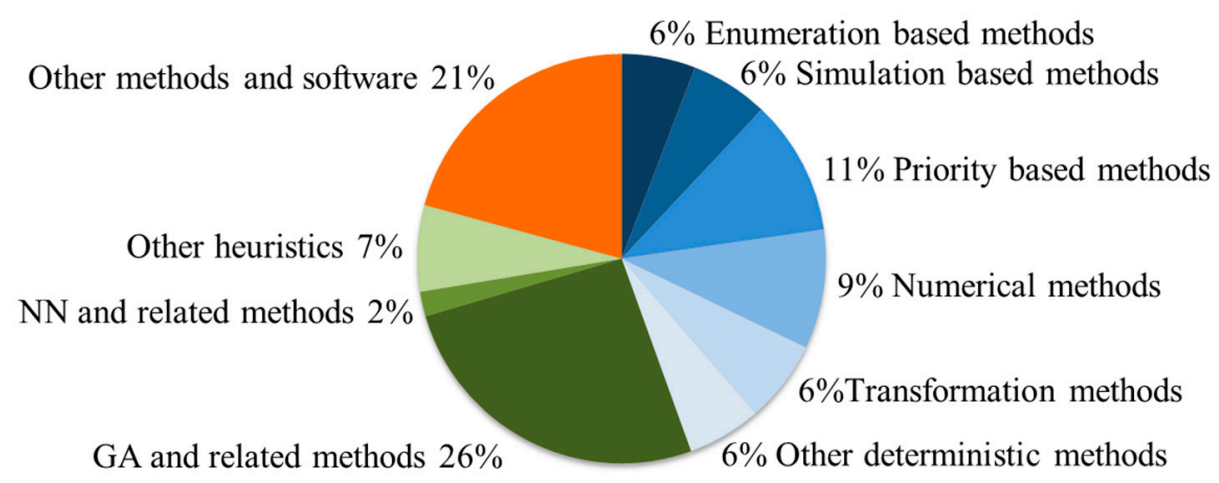

Figure 6. Optimization methods applied by the reviewed articles.

\subsubsection{Deterministic Methods}

The most popular deterministic methods are the priority-based methods, with an application percentage of $11 \%$. They measure the priority of management options by exploring measurement criteria, weighting the criteria, and scoring the options accordingly. The highest-priority option is finally selected. These methods can be applied to SOO $[21,55]$ and MOO, especially when optimizing several management criteria or objectives [56-58]. These methods can help in specifying the relationship of management outcomes in terms of measurement criteria. However, these methods require expert adjustment to make the rules of priority before or during optimization procedure and only produce one solution, based on the priority. They are recommended when sufficient knowledge is obtained to support the expert adjustment and to build the priority system. When the problems are complicated, a proper priority system may not be easily built.

Another popular group of deterministic methods in this paper is the so-called numerical methods. A total of $9 \%$ of the reviewed articles apply these types of methods in their DM. They build mathematical models and then compute the optimal solution following specific algorithms. They 
have been applied to help with IAM since 1975 [12]. Different algorithms are proposed and applied, including linear programming [59-61], dynamic programming [62,63], dual programming [64], and branch and bound [65]. Additionally, with the help of powerful computers, numerical methods can efficiently solve decision making problems and obtain the optimal solution or Pareto solutions. They also can be incorporated in management software tools [66,67]. According to the reviewed articles, numerical methods are mainly applied to SOO or used as a solver for MOO. These methods often follow strict requirements and algorithms, which may result in a limited application scope. Hence, they are recommended for large-sized DM problems, especially when the outcome relationships are simple.

Enumeration based methods are one of the earliest and the most effective optimization methods when assisting IAM. They enumerate the possible options and select the best one(s). They can handle various DM problems, including complicated ones. Enumeration based methods can easily handle both $\mathrm{SOO}$ and $\mathrm{MOO}$ and guarantee to obtain the optimal solution (SOO) [68-70] or all the existing Pareto solutions (MOO) [71-73]. Compared to other deterministic methods the conventional enumeration-based methods, e.g., decision trees, are time consuming. Hence, they are recommended for problems with small networks and complicated problems where outcome relationships cannot be accurately described as mathematical formulae. The acceleration is necessary when analyzing large networks.

A total of 20 of the reviewed articles adopted transformation-based methods in their IAM. These methods transform a MOO problem into a SOO sub-problem or a set of $\mathrm{SOO}$ sub-problems and then solve the sub-problem(s) individually. Hence, they are widely applied to handle MOO problems for DM. The most commonly used transformation based method is the weighted sum method, which weighted sums all the objectives into one using a weighting system [74-76]. Transformation based methods can obtain a Pareto solution or a set of Pareto solutions. With the help of powerful computers, they can quickly analyze large problems, i.e., life-cycle analysis of large networks. However, these methods may not obtain the entire set of existing Pareto solutions. Additionally, these methods cannot directly solve an optimization problem but, rather, transform it into a sub-problem(s) and a solver is needed to solve the sub-problem(s). They are highly recommended for MOO, with a powerful solver, especially for hard DM, e.g., large-sized networks, life-cycle analysis, and complicated DM problems.

Similarly, simulation-based methods also contributed $6 \%$ of the applications among the reviewed articles. These methods simulate the behavior of the infrastructure assets after applying alternative management strategies/interventions and explore the uncertainties and risks during the management. A Markov chain is a popular choice for simulation based methods to simulate the infrastructure performance [77-79]. Simulation based methods can better describe the deterioration of infrastructure condition and, therefore, can consider the uncertainties during the optimization process. Yet, for large networks or complicated problems, the simulations may be too complex and these methods may not be efficient. Hence, these methods are recommended for small and simple DM, where infrastructure asset condition and uncertainties are important considerations in the DM.

In general, deterministic methods are the most popular choice for IAM among the reviewed articles. A main reason of their popularity is that they are effective and efficient when supporting management decisions. They can generate high-quality solutions for both $\mathrm{SOO}$ and $\mathrm{MOO}$. According to the reviewed articles, their solution quality is stable and not affect by problem size and the restrictiveness of constraints. With the help of powerful computers, they are able to complete life-cycle analysis of large infrastructure networks in reasonable times. Considering the solution quality, deterministic methods are highly recommended for DM in IAM. However, deterministic methods follow specific algorithms with application limitations and restrictions. Hence, they may be ineffective for some types of problems in IAM.

\subsubsection{Heuristics}

Genetic algorithms (GA) and related methods are the most popular choice for MOO, with a percentage of $26 \%$, as shown in Figure 6. These methods are based on the classic GA that defines 
the management strategies or interventions as genes and then simulates the crossover and mutation of genes to create solutions [80]. For a better performance, improvements are proposed for the classic algorithm to handle SOO targeting at the optimal solution $[48,81,82]$ and MOO targeting at a preferred Pareto solution [83-85] or a set of Pareto solutions [86-88]. The GA and related methods are flexible, easily controlled, and can handle a variety of DM problems, including the complicated ones. Comparing with other heuristics, GAs often generate better solutions and have higher efficiency. These methods are recommended when DM problems are too complicated to be easily handled by deterministic methods. When analyzing large-sized problems, these methods may produce poor solutions.

Neural networks (NN) and related methods are also applied in DM in IAM. They build a multi-layer network to analyze management outcomes and explore their relationships and their influence on the management plans. They can handle various objectives and constraints in terms of network inputs $[89,90]$. NN can effectively handle different management outcomes, even when the relationship of management outcomes is fuzzy or unclear. They are often applied for small infrastructure asset networks and may not be efficient for large ones.

Other heuristics are also introduced to assist management decisions for IAM, including Greedy heuristic [28,91,92], particle swarm optimization [93,94], and simulated annealing [95].

Heuristics, with 107 applications in the reviewed articles, are also a common choice for IAM. They are proposed as a general-purpose algorithmic framework, which largely increases their flexibility and robustness. Hence, they can handle a variety of DM problems, even the hard and complicated ones. Additionally, the understanding, application, and implementation of their algorithms is easy. However, the solution quality of heuristics is affected by a range of factors including problem size, constraint restriction, parameter calibration, etc. They may fail to obtain the optimal solution (SOO) and Pareto solutions (MOO), especially for the large-sized DM problems. Thus, heuristics are recommended when the problem cannot be easily solved by the deterministic methods. When applying a heuristic, several trials are suggested to confirm that the adopted algorithm calibration can produce the stable and good optimization result for the addressed DM problem.

\subsubsection{Other Methods and Software}

Other methods and software tools are developed to help with DM in IAM e.g., AASHTO software [96], GENEPAV-HDM4 software [97], OPTIPAV system [27], and feedback models [98]. These methods and software tools, especially the commercial ones, are well-organized with effective optimization algorithms. Some software tools even involve multiple algorithms. They are highly recommended when decision makers do not want to do the optimization by themselves.

\subsection{Management Outcomes}

DM in IAM may involve a wide range of outcomes and optimization methods can analyze various outcomes in terms of objectives and constraints. The financial expense of management interventions is the most popular and important outcome in IAM. Over $60 \%$ of the reviewed articles attempt to reduce the expense (objective) and around $40 \%$ of the articles have a management budget (constraint). The main types of expenses are infrastructure user cost [78,99,100], M\&R treatment cost [101-103], asset management agency cost $[87,100,104]$, and the total life-cycle cost $[48,105,106]$. However, the exact calculation of the expenses may vary from case to case. Optimization can also help in allocating limited funds across different types of infrastructure assets, working zones, or management projects [107-109].

Infrastructure asset condition is also an important outcome. The goal of IAM is to keep infrastructure assets in good condition in order to provide the required level of service. Around a quarter of the reviewed articles directly optimize infrastructure asset condition [110-112] or keep the condition at an acceptable level $[44,87,113]$. 
Level of service, as another criterion to assess the infrastructure, obtains increasing attention and applications $[11,114,115]$. Rather than an average index, it measures the performance of infrastructure in a better and more meaningful manner.

Besides the traditional outcomes, other outcomes are also analyzed with optimization, depending on the addressed problems, e.g., traffic [116-118], risk [49,119,120], investment efficiency [35,77,121], and greenhouse emission $[48,63,91]$. These outcomes indicate the deep and wide thinking when making management decisions. Presently, IAM does not only trade-off of expense and infrastructure condition but also looks at the needs of different parties and aspects. With the assist of optimization, the analysis of different outcomes becomes possible.

\section{Conclusions and Future Research}

This paper presents a comprehensive overview of the applications of optimization methods in DM in IAM. As a consequence of their intelligence, optimization methods are increasingly applied to assist DM and facilitate IAM. This paper, based on a review of 337 articles, introduces, summarizes, and discusses the achievements on this subject. According to the review, it concludes the following:

- Optimization can greatly assist DM in IAM. It analyzes DM problems even for the large infrastructure networks and life-cycle analysis and attempts to generate the best solution(s) under the goals and requirements of IAM. Therefore, DM becomes easier and more informed and its result is more reasonable and more objective.

- Optimization methods have been applied in DM in IAM for a long time and became popular in the 2000s.

- IAM has the following two types of DM: Project- and network-level, where the former is often used for a specific project and the latter is often used to analyze an infrastructure network when deciding the M\&R management.

- DM problems can be defined as SOO or MOO depending on the number of the main goals. Optimization methods can handle both and generate one solution or a set of solutions accordingly.

- There are a broad range of optimization methods that can be applied to assist DM in IAM. This paper summarizes the popular optimization methods within the classes of deterministic methods, heuristics, and other methods and software. These methods have their strengths and weaknesses. The recommendations and suggestions on their applications are also made.

- DM may involve various management outcomes which can be analyzed by optimization methods in terms of objectives and constraints. The common outcomes include financial expense and infrastructure asset condition, while other outcomes are also considered.

Optimization is a useful tool for DM in IAM and great achievements are gained by the articles. Its significance is widely admitted by researchers and practitioners. However, with the development of IAM, DM becomes more complex. Firstly, an essential issue in IAM is to keep the infrastructure condition at an acceptable level. This requires an accurate model and prediction of the infrastructure deterioration, while the deterioration is affected by the changing environment and filled with uncertainties. Hence the prediction of infrastructure condition over the long-term is still a critical topic.

Moreover, private actors play an important role in IAM. Public agencies and private investors have different intention when managing infrastructure assets. How to consider their roles and satisfy their requirements in IAM is another important topic.

Additionally, each DM problem is unique and none of the optimization methods is a panacea. All of the algorithms have their strengths and limitations. Hence, the selection of a proper optimization algorithm depends on the addressed problem.

While optimization is mathematics and it tries to correctly describe practical DM problems, it is worth noticing that there is always a gap between practical problems and mathematical models. Decision makers should carefully examine their problems and tailor the optimization results in order to make more practical decisions for the addressed DM problems. 
This paper is based on a total of 337 articles, while these articles do not cover all the published articles on this subject and some sound articles may be missed. This paper focuses on the optimization algorithms and other subjects are briefly discussed.

Funding: This research was funded by the Fundamental Research Funds for the Central Universities (Grant No. 300102218101, 300102218401, 300102218302).

Conflicts of Interest: The authors declare no conflict of interest.

\section{Appendix A}

In this paper, a total of 337 articles are reviewed and discussed to obtain a comprehensive understanding of the application of optimization in DM in IAM. The reviewed articles are listed below in the order of their published years.

1. Abelson, P.W.; Flowerdew, A.D.J. Models for the economic evaluation of road Maintenance. J. Transp. Econ. Policy 1975, 4, 93-114.

2. Friesz, T.L.; Fernandez, J.E. A model of optimal transport maintenance with demand responsiveness. Transp. Res. Part B. 1979, 13, 317-339.

3. Kemp, F.O. Optimization of road maintenance in Sabah: accountants and engineers team up on cost accounting. Proceedings of the 4th Conference on Road Engineering Association of Asia and Australasia, Jakarta, Indonesia, 1983; Volume 4, pp. 81-103.

4. Moghtaderi-Zadeh, M.; Kiureghian, A. Der Reliability upgrading of lifeline networks for post-earthquake serviceability. Earthq. Eng. Struct. Dyn. 1983, 11, 557-566.

5. Cook, W.D. Goal programming and financial planning models for highway rehabilitation. J. Oper. Res. Soc. 1984, 53, 217-223.

6. Way, G.B. Network optimization system for Arizona. Proceedings of the 1st North American Pavement Managment Conference, Toronto, Canada, 1985; pp. 16-22.

7. Fwa, T.; Sinha, K.; Riverson, J. Highway Routine Maintenance Programming at Network Level. J. Transp. Eng. 1988, 114, 539-554.

8. Jiang, Y.; Sinha, K.C. Dynamic optimization model for bridge management systems. Transp. Res. Rec. 1989, 92-100.

9. Azis, I.J. Analytic Hierarchy Process in the benefit-cost framework: A post-evaluation of the Trans-Sumatra highway project. Eur. J. Oper. Res. 1990, 48, 38-48.

10. Male, J.; Walski, T.; Slutsky, A. Analyzing Water Main Replacement Policies. J. Water Resour. Plan. Manag. 1990, 116, 362-374.

11. Jacobs, T. Optimal Long-Term Scheduling of Bridge Deck Replacement and Rehabilitation. J. Transp. Eng. 1992, 118, 312-322.

12. Lansey, K.E.; Basnet, C.; Mays, L.W.; Woodburn, J. Optimal maintenance scheduling for water distribution systems. Civ. Eng. Syst. 1992, 9, 211-226.

13. Li, D.; Haimes, Y.Y. Optimal maintenance-related decision making for deteriorating water distribution systems. Water Resour. Res. 1992, 28, 1053-1061.

14. Ben-Akiva, M.; Humplick, F.; Madanat, S.; Ramaswamy, R. Infrastructure management under uncertainty: Latent Performance Approach. J. Transp. Eng. 1993, 119, 43-58.

15. Fwa, T.F.; Chan, W.T. Priority rating of highway maintenance needs by neural networks. J. Transp. Eng. 1993, $119,419-432$.

16. Grivas, D.A.; Ravirala, V.; Schultz, B.C. State increment optimization methodology for network-level pavement management. Transp. Res. Rec. 1993, 25-33.

17. Sikow, C.; Tikka, K.; Aijo, J. Programme management in highway region. Proceedings of the Pacific Rim TransTech Conference, Washington D.C., USA, 1993; pp. 202-208.

18. Augusti, G.; Borri, A.; Ciampoli, M. Optimal allocation of resources in reduction of the seismic risk of highway networks. Eng. Struct. 1994, 16, 485-497.

19. Chan, W.T.; Fwa, T.F.; Tan, C.Y. Road-maintenance planning using genetic algorithms I: Formulation. J. Transp. Eng. 1994, 120, 693-709. 
20. Farid, F.; Johnston, D.W.; Laverde, M.A.; Chen, C.-J. Application of incremental benefit-cost analysis for optimal budget allocation to maintenance, rehabilitation, and replacement of bridges. Transp. Res. Rec. 1994, 88-100.

21. Fwa, T.F.; Tan, C.Y.; Chan, W.T. Road-maintenance planning using genetic algorithms II: Analysis. J. Transp. Eng. 1994, 120, 710-722.

22. Kim, J.; Mays, L. Optimal Rehabilitation Model for Water-Distribution Systems. J. Water Resour. Plan. Manag. 1994, 120, 674-692.

23. Arulraj, G.; Rao, H. Concept of Significance Index for Maintenance and Design of Pipe Networks. J. Hydraul. Eng. 1995, 121, 833-837.

24. Mohamed, H.A.; Abd El Halim, A.O.; Razaqpur, A.G. Use of neural networks in bridge management systems. Transp. Res. Rec. 1995, 1490, 1-8.

25. Mohammadi, J.; Guralnick, S.; Yan, L. Incorporating Life-Cycle Costs in Highway-Bridge Planning and Design. J. Transp. Eng. 1995, 121, 417-424.

26. Flintsch, G.W.; Zaniewski, J.P.; Delton, J. Artificial neural network for selecting pavement rehabilitation projects. 1996, 1524, 185-193.

27. Fwa, T.F.; Chan, W.T.; Tan, C.Y. Genetic-algorithm programming of road maintenance and rehabilitation. J. Transp. Eng. 1996, 122, 246-253.

28. Harper, W. V Highway maintenance quality optimization. J. Qual. Maint. Eng. 1996, 2, 81-93.

29. Liu, F.; Wang, K. Pavement Performance-Oriented Network Optimization System. Transp. Res. Rec. J. Transp. Res. Board 1996, 1524, 86-93.

30. Mbwana, J.; Turnquist, M. Optimization Modeling for Enhanced Network-Level Pavement Management System. Transp. Res. Rec. J. Transp. Res. Board 1996, 1524, 76-85.

31. Razaqpur, A.G.; Abd El Halim, A.O.; Mohamed, H.A. Bridge management by dynamic programming and neural networks. Can. J. Civ. Eng. 1996, 23, 1064-1069.

32. Sebaaly, P.; Hand, A.; Epps, J.; Bosch, C. Nevada's Approach to Pavement Management. Transp. Res. Rec. J. Transp. Res. Board 1996, 1524, 109-117.

33. Tam, C.K.; Stiemer, S.F. Bridge corrosion cost model implementation and coating maintenance model using dynamic programming. J. Perform. Constr. Facil. 1996, 10, 57-66.

34. Wang, K.C.P.; Zaniewski, J.P. 20/30 hindsight: the new pavement optimization in the Arizona state highway network. Interfaces (Providence). 1996, 26, 77-89.

35. Bellehumeur, C.; Vasseur, L.; Ansseau, C.; Marcos, B. Implementation of a multicriteria sewage sludge management model in the southern Quebec municipality of Lac-Megantic, Canada. J. Environ. Manage. 1997, 50, 51-66.

36. Frangopol, D.M.; Lin, K.Y.; Estes, A.C. Life-cycle cost design of deteriorating structures. J. Struct. Eng. 1997, 123, 1390-1401.

37. Fwa, T.F.; Chan, W.T.; Lim, C.T. Decision framework for pavement friction management of airport runways. J. Transp. Eng. 1997, 123, 429-435.

38. Halhal, D.; Walters, G.A.; Ouazar, D.; Savic, D.A. Water network rehabilitation with structured messy genetic algorithm. J. Water Resour. Plan. Manag. 1997, 123, 137-146.

39. Hicks, R.G.; Dunn, K.; Moulthrop, J.S. Framework for selecting effective preventive maintenance treatments for flexible pavements. Transp. Res. Rec. J. Transp. Res. Board 1997, 1597, 1-10.

40. Itoh, Y.; Hammad, A.; Liu, C.; Shintoku, Y. Network-Level Bridge Life-Cycle Management System. J. Infrastruct. Syst. 1997, 3, 31-39.

41. Li, N.; Huot, M.; Haas, R. Cost-effectiveness-based priority programming of standardized pavement maintenance. Transp. Res. Rec. J. Transp. Res. Board 1997, 1592, 8-16.

42. Liu, C.; Hammad, A.; Itoh, Y. Multiobjective Optimization of Bridge Deck Rehabilitation Using a Genetic Algorithm. Comput. Civ. Infrastruct. Eng. 1997, 12, 431-443.

43. Sirajuddin, A. Highway maintenance fund allocation:tabulated manual procedure. J. Transp. Eng. 1997, 123, 346-349.

44. Augusti, G.; Ciampoli, M. Multi-objective optimal allocation of resources to increase the seismic reliability of highways. Math. Methods Oper. Res. 1998, 47, 131-164. 
45. Augusti, G.; Ciampoli, M.; Frangopol, D.M. Optimal planning of retrofitting interventions on bridges in a highway network. Eng. Struct. 1998, 20, 933-939.

46. Fwa, T.F.; Shanmugam, R. Fuzzy Logic Technique for Pavement Condition Rating and Maintenance-Needs Assessment. Proceedings of the Fourth International Conference on Managing Pavements, Durban, South Africa, 1998, pp. 465-476.

47. Kleiner, Y.; Adams, B.J.; Rogers, J.S. Long-term planning methodology for water distribution system rehabilitation. Water Resour. Res. 1998, 34, 2039-2051.

48. Kleiner, Y.; Adams, B.J.; Rogers, J.S. Selection and scheduling of rehabilitation alternatives for water distribution systems. Water Resour. Res. 1998, 34, 2053-2061.

49. Abaza, K.; Ashur, S. Optimum Decision Policy for Management of Pavement Maintenance and Rehabilitation. Transp. Res. Rec. J. Transp. Res. Board. 1999, 1655, 8-15.

50. Das, P.C. Prioritization of bridge maintenance needs. In Case Study in optimal design and maintenance planning of civil infrastructure systems; Frangopol, D.M., American Society of Civil Engineers: Reston, USA, 1999; pp. 26-44.

51. Frohwein, H.; Lambert, J.; Haimes, Y.; Schiff, L. Multicriteria Framework to Aid Comparison of Roadway Improvement Projects. J. Transp. Eng. 1999, 125, 224-230.

52. Guignier, F.; Madanat, S. Optimization of infrastructure systems maintenance and improvement policies. J. Infrastruct. Syst. 1999, 5, 124-134.

53. Halhal, D.; Walters, G.; Savic, D.; Ouazar, D. Scheduling of Water Distribution System Rehabilitation Using Structured Messy Genetic Algorithms. Evol. Comput. 1999, 7, 311-329.

54. Kerali, H.R.; Mannisto, V. Prioritization methods for strategic planning and road work programming in a new highway development and management tool. Transp. Res. Rec. J. Transp. Res. Board 1999, 1655, 49-54.

55. Kiyota, M.; Vandebona, U.; Tanoue, H. Multistage optimization of reconstruction sequence of highways. J. Transp. Eng. 1999, 125, 456-462.

56. Abdelrahim, A.M.; George, K.P. Artificial neural network for enhancing selection of pavement maintenance strategy. Transp. Res. Rec. J. Transp. Res. Board 2000, 1699, 16-22.

57. Boulos, P.; Wu, Z.; Heath, J.; Hauffen, P. Optimal Design and Rehabilitation of Water Distribution Systems. Proceedings of the Joint Conference on Water Resource Engineering and Water Resources Planning and Management, Minneapolis, USA, 2000; pp. 1-8.

58. Frangopol, D.; Gharaibeh, E.; Kong, J.; Miyake, M. Optimal Network-Level Bridge Maintenance Planning Based on Minimum Expected Cost. Transp. Res. Rec. J. Transp. Res. Board 2000, 1696, 26-33.

59. Frangopol, D.; Miyake, M.; Kong, J.; Gharaibeh, E. Reliability- and Cost-Oriented Optimal Bridge Maintenance Planning. In Advanced Technology in Structural Engineering; American Society of Civil Engineers: Philadelphia, USA, 2000; pp. 1-8.

60. Fwa, T.F.; Chan, W.T.; Hoque, K.Z. Multiobjective optimization for pavement maintenance programming. J. Transp. Eng. 2000, 126, 367-374.

61. Hawker, L.; Abell, R. Selection and prioritisation of maintenance works on major roads in England. Proceedings of the First European Pavement Mangement System Conference, Budapest, Hungary, 2000; pp. 1-9.

62. Miyamoto, A.; Kawamura, K.; Nakamura, H. Bridge Management System and Maintenance Optimization for Existing Bridges. Comput. Civ. Infrastruct. Eng. 2000, 15, 45-55.

63. Smilowitz, K.; Madanat, S. Optimal inspection and maintenance policies for infrastructure networks. Comput. Civ. Infrastruct. Eng. 2000, 15, 5-13.

64. Abaza, K.; Ashur, S.; Abu-Eisheh, S.; Rabay'a, A. Macroscopic Optimum System for Management of Pavement Rehabilitation. J. Transp. Eng. 2001, 127, 493-500.

65. Attoh-Okine, N.O.; Gibbons, J. Use of belief function in brownfield infrastructure redevelopment decision making. J. urban Plan. Dev. 2001, 127, 126-143.

66. Chan, W.T.; Fwa, T.F.; Hoque, K.Z. Constraint handling methods in pavement maintenance programming. Transp. Res. Part C Emerg. Technol. 2001, 9, 175-190.

67. Dandy, G.; Engelhardt, M. Optimal Scheduling of Water Pipe Replacement Using Genetic Algorithms. J. Water Resour. Plan. Manag. 2001, 127, 214-223. 
68. Dogaki, M.; Furuta, H.; Tsukiyama, I.; Frangopol, D. Optimal Maintenance Planning of Reinforced Concrete Decks on Highway Network. In Life-Cycle Cost Analysis and Design of Civil Infrastructure Systems; 2001; pp. 107-119.

69. Frangopol, D.; Kong, J.; Gharaibeh, E. Reliability-Based Life-Cycle Management of Highway Bridges. J. Comput. Civ. Eng. 2001, 15, 27-34.

70. Jha, M.K.; McCall, C.; Schonfeld, P. Using GIS, Genetic Algorithms, and visualization in highway development. Comput. Civ. Infrastruct. Eng. 2001, 16, 399-414.

71. Kleiner, Y. Scheduling inspection and renewal of large infrastructure assets. Int. Conf. Undergr. Infrastruct. Res. 2001, 7, 136-142.

72. Kleiner, Y.; Adams, B.J.; Rogers, J.S. Water distribution network renewal planning. J. Comput. Civ. Eng. 2001, 15, 15-26.

73. Mamlouk, M.S.; Zaniewski, J.P. Optimizing Pavement Preservation: An Urgent Demand for Every Highway Agency. Int. J. Pavement Eng. 2001, 2, 135-148.

74. Morley, M.S.; Atkinson, R.M.; Savić, D.A.; Walters, G.A. GAnet: genetic algorithm platform for pipe network optimisation. Adv. Eng. Softw. 2001, 32, 467-475.

75. Najafi, F.; Valerie, B. Cost-benefit highway pavement maintenance. Transp. Res. Rec. J. Transp. Res. Board 2001, 1749, 22-27.

76. Smadi, O. Knowledge based expert system pavement management optimization. Fifth Int. Conf. Manag. Pavements 2001, 1-13.

77. Abaza, K. Optimum flexible pavement life-cycle analysis model. J. Transp. Eng. 2002, 128, 542-549.

78. Bonyuet, M.; Garcia-Diaz, A.; Hicks, I. Optimization procedures for simultaneous road rehabilitation and bridge replacement decisions in highway networks. Eng. Optim. 2002, 34, 445-459.

79. Cafiso, S.; Di Graziano, A.; Kerali, H.; Odoki, J. Multicriteria analysis method for pavement maintenance management. Transp. Res. Rec. J. Transp. Res. Board 2002, 1816, 73-84.

80. Chien, S.; Tang, Y.; Schonfeld, P. Optimizing work zones for two-lane highway maintenance projects. J. Transp. Eng. 2002, 128, 145-155.

81. Durango, P. Reinforcement learning models for Transportation Infrastructure Management. Proceedings of the International Conference on Applications of Advanced Technologies in Transportation, Cambridge, UK, 2002; pp. 568-575.

82. Evdorides, H.; R. Kerali, H.; Rivière, N.; Ørnskov, J. Condition-Based Method for Programming Road Infrastructure Maintenance. Transp. Res. Rec. J. Transp. Res. Board 2002, 1816, 10-15.

83. Ferreira, A.; Picado-Santos, L.; Antunes, A. A Segment-linked Optimization Model for Deterministic Pavement Management Systems. Int. J. Pavement Eng. 2002, 3, 95-105.

84. Ferreira, A.; Antunes, A.; Picado-Santos, L. Probabilistic Segment-linked Pavement Management Optimization Model. J. Transp. Eng. 2002, 128, 568-577.

85. Tack, J.; Chou, E.J. Multiyear Pavement Repair Scheduling Optimization by Preconstrained Genetic Algorithm. Transp. Res. Rec. J. Transp. Res. Board 2002, 1816, 3-8.

86. Ziara, M.; Nigim, K.; Enshassi, A.; Ayyub, B.M. Strategic implementation of infrastructure priority projects: case study in Palestine. J. Infrastruct. Syst. 2002, 8, 2-11.

87. Chan, W.T.; Fwa, T.F.; Tan, J.Y. Optimal Fund-Allocation Analysis for Multidistrict Highway Agencies. J. Infrastruct. Syst. 2003, 9, 167-175.

88. Ferrari, P. A method for choosing from among alternative transportation projects. Eur. J. Oper. Res. 2003, 150, 194-203.

89. Hassanain, M.A.; Loov, R.E. Cost optimization of concrete bridge infrastructure. Can. J. Civ. Eng. 2003, 30, 841-849.

90. Kong, J.; Frangopol, D. Evaluation of Expected Life-Cycle Maintenance Cost of Deteriorating Structures. J. Struct. Eng. 2003, 129, 682-691.

91. Kong, J.; Frangopol, D. Life-Cycle Reliability-Based Maintenance Cost Optimization of Deteriorating Structures with Emphasis on Bridges. J. Struct. Eng. 2003, 129, 818-828. 
92. Streicher, H.; Rackwitz, R. Renewal models for optimal life-cycle cost of aging civil infrastructures. Proceedings of the IABMAS workshop on life-cycle cost analysis and design of civil infrastructure systems and JCSS workshop on probabilistic modeling of deterioration processes in concrete structures, Lausanne, Switzerland, 2003; volumn 24, pp. 401-412.

93. Tsunokawa, K.; Ul-Islam, R. Optimal pavement design and maintenance strategy for developing countries: an analysis using HDM-4. Int. J. Pavement Eng. 2003, 4, 193-208.

94. Wang, F.; Zhang, Z.; Machemehl, R.B. Decision-making problem for managing pavement maintenance and rehabilitation projects. Transp. Res. Rec. J. Transp. Res. Board 2003, 1853, 21-28.

95. Yang, J.; Lu, J.; Gunaratne, M.; Xiang, Q. Forecasting Overall Pavement Condition with Neural Networks: Application on Florida Highway Network. Transp. Res. Rec. J. Transp. Res. Board 2003, 1853, 3-12.

96. Abaza, K.; Ashur, S.; Al-Khatib, I. Integrated Pavement Management System with a Markovian Prediction Model. J. Transp. Eng. 2004, 130, 24-33.

97. Adey, B.; Hajdin, R.; Brühwiler, E. Effect of common cause failures on indirect costs. J. Bridg. Eng. 2004, 9, 200-208.

98. Dicdican, R.Y. Risk-based asset management for hierarchical dynamic multiobjective systems: theory, methodology, and application. Ph.D. Thesis, University of Virginia, Virginia, USA, 2004.

99. Frangopol, D.M.; Neves, L.C. Probabilistic maintenance and optimization strategies for deteriorating civil infrastructures. Proceedings of the Progress In Computational Structures Technology; Saxe-Coburg Publications: Kippen, UK, 2004; pp. 1-25.

100. Furuta, H.; Kameda, T.; Fukuda, Y.; Frangopol, D.M. Life-cycle cost analysis for infrastructure systems: Life cycle cost vs. safety level vs. service life. Life-cycle Perform. Deterior. Struct. Assessment, Des. Manag. 2004, 19-25.

101. Hsieh, T.; Liu, H. Genetic Algorithm for Optimization of Infrastructure Investment Under Time-Resource Constraints. Comput. Civ. Infrastruct. Eng. 2004, 19, 203-212.

102. Kulkarni, R.; Miller, D.; Ingram, R.; Wong, C.; Lorenz, J. Need-Based Project Prioritization: Alternative to Cost-Benefit Analysis. J. Transp. Eng. 2004, 130, 150-158.

103. Liu, M.; Frangopol, D.M. Optimal bridge maintenance planning based on probabilistic performance prediction. Eng. Struct. 2004, 26, 991-1002.

104. Noortwijk, J.M. van; Frangopol, D.M. Two probabilistic life-cycle maintenance models for deteriorating civil infrastructures. Probabilistic Eng. Mech. 2004, 19, 345-359.

105. Nunoo, C.; Mrawira, D. Shuffled Complex Evolution Algorithms in Infrastructure Works Programming. J. Comput. Civ. Eng. 2004, 18, 257-266.

106. Picado-Santos, L.; Ferreira, A.; Antunes, A.; Carvalheira, C.; Santos, B.; Bicho, M.; Quadrado, I.; Silvestre, S. Pavement management system for Lisbon. Proc. ICE - Munic. Eng. 2004, 157, 157-165.

107. Stewart, M.; Estes, A.; Frangopol, D. Bridge Deck Replacement for Minimum Expected Cost Under Multiple Reliability Constraints. J. Struct. Eng. 2004, 130, 1414-1419.

108. Tan, J.Y.; Chan, W.T.; Fwa, T.F. Interactive budget allocation concept for pavement management. Proceedings of the 6th international conference on managing pavements, Queensland, Australia, 2004.

109. Yoo, J. Multi-period optimization of pavement management systems, Texas A\&M University: Texas, USA, 2004.

110. Zayed, T. Budget Allocation for Steel Bridge Paint Maintenance. J. Perform. Constr. Facil. 2004, 18, 36-46.

111. Bakó, A.; Ambrussomogyi, K. Maintenance and Rehabilitation Systems of Infrastructures Management. Acta Polytech. Hungarica 2005, 2, 91-102.

112. Chassiakos, A.P.; Vagiotas, P.; Theodorakopoulos, D.D. A knowledge-based system for maintenance planning of highway concrete bridges. Adv. Eng. Softw. 2005, 36, 740-749.

113. Parke, G.A.; Disney, P.; Frangopol, D.M.; Liu, M. Bridge management based on multiple-objective optimization. Proceedings of the 5th International Conference on Bridge Management; Thomas Telford Limited, Wokingham, UK, 2005; pp. 235-242.

114. Herabat, P.; Tangphaisankun, A. Multi-Objective Optimization Model using Constraint-Based Genetic Algorithms for Thailand Pavement Management. J. East. Asia Soc. Transp. Stud. 2005, 6, 1137-1152. 
115. Hiep, D. Van; Tsunokawa, K. Optimal maintenance strategies for bituminous pavements: a case study in Vietnam using HDM-4 with gradient methods. J. East. Asia Soc. Transp. Stud. 2005, 6, 1123-1136.

116. Hugo, A.; Rutter, P.; Pistikopoulos, S.; Amorelli, A.; Zoia, G. Hydrogen infrastructure strategic planning using multi-objective optimization. Int. J. Hydrogen Energy 2005, 30, 1523-1534.

117. Kong, J.; Frangopol, D. Probabilistic Optimization of Aging Structures Considering Maintenance and Failure Costs. J. Struct. Eng. 2005, 131, 600-616.

118. Kuhn, K.D.; Madanat, S.M. Model uncertainty and the management of a system of infrastructure facilities. Transp. Res. Part C Emerg. Technol. 2005, 13, 391-404.

119. Lee, E.-B.; Harvey, J.; Samadian, M. Knowledge-Based Scheduling Analysis Software for Highway Rehabilitation and Reconstruction Projects. Transp. Res. Rec. J. Transp. Res. Board 2005, 1907, 15-24.

120. Liu, M.; Frangopol, D. Balancing Connectivity of Deteriorating Bridge Networks and Long-Term Maintenance Cost through Optimization. J. Bridg. Eng. 2005, 10, 468-481.

121. Liu, M.; Frangopol, D. Multiobjective Maintenance Planning Optimization for Deteriorating Bridges Considering Condition, Safety, and Life-Cycle Cost. J. Struct. Eng. 2005, 131, 833-842.

122. Liu, M.; Frangopol, D.M. Managing bridge networks using reliability and multiple cost criteria. Proceedings of the First CSCE specialty conference on infrastructure technologies, management and policy, Toronto, Canada, 2005, pp. 22-25.

123. Liu, M.; Frangopol, D.M. Bridge annual maintenance prioritization under uncertainty by multiobjective combinatorial optimization. Comput. Civ. Infrastruct. Eng. 2005, 20, 343-353.

124. Lounis, Z. Network-level bridge management using a multiobjective optimization decision model. Proceedings of the First CSCE specialty conference on infrastructure technologies, management and policy, Toronto, Canada, 2005, 121-131.

125. Morcous, G.; Lounis, Z. Maintenance optimization of infrastructure networks using genetic algorithms. Autom. Constr. 2005, 14, 129-142.

126. Neves, L.C.; Frangopol, D.M. Condition, safety and cost profiles for deteriorating structures with emphasis on bridges. Reliab. Eng. Syst. Saf. 2005, 89, 185-198.

127. Singh, D.; Tiong, R.L.K. Development of life cycle costing framework for highway bridges in Myanmar. Int. J. Proj. Manag. 2005, 23, 37-44.

128. Abaza, K. Iterative Linear Approach for Nonlinear Nonhomogenous Stochastic Pavement Management Models. J. Transp. Eng. 2006, 132, 244-256.

129. Bucher, C.; Frangopol, D.M. Optimization of lifetime maintenance strategies for deteriorating structures considering probabilities of violating safety, condition, and cost thresholds. Probabilistic Eng. Mech. 2006, 21, 1-8.

130. Chen, W.; Zhang, R.T.; Cai, Y.M.; Xu, F.S. Particle swarm optimization for constrained portfolio selection problems. Proceedings of the 2006 International Conference on Machine Learning and Cybernetics, Dalian, China, 2006, pp. 2425-2429.

131. Chootinan, P.; Chen, A.; Horrocks, M.R.; Bolling, D. A multi-year pavement maintenance program using a stochastic simulation-based genetic algorithm approach. Transp. Res. Part A Policy Pract. 2006, 40, 725-743.

132. Dandy, G.; Engelhardt, M. Multi-Objective Trade-Offs between Cost and Reliability in the Replacement of Water Mains. J. Water Resour. Plan. Manag. 2006, 132, 79-88.

133. Durango-Cohen, P.; Tadepalli, N. Using Advanced Inspection Technologies to Support Investments in Maintenance and Repair of Transportation Infrastructure Facilities. J. Transp. Eng. 2006, 132, 60-68.

134. Elbehairy, H.; Elbeltagi, E.; Hegazy, T.; Soudki, K. Comparison of Two Evolutionary Algorithms for Optimization of Bridge Deck Repairs. Comput. Civ. Infrastruct. Eng. 2006, 21, 561-572.

135. Furuta, H.; Nakatsu, K.; Frangopol, D.M. Optimal cost allocation for improving the seismic performance of road networks. Proceedings of the 3rd international conference on bridge maintenance, safety and management-Bridge maintenance, safety, management, life-cycle performance and cost, Porto, Portugal, 2006, pp. 143-144.

136. Jha, M.K.; Abdullah, J. A Markovian approach for optimizing highway life-cycle with genetic algorithms by considering maintenance of roadside appurtenances. J. Franklin Inst. 2006, 343, 404-419. 
137. Liu, M.; Frangopol, D. Optimizing Bridge Network Maintenance Management under Uncertainty with Conflicting Criteria: life-Cycle Maintenance, Failure, and User Costs. J. Struct. Eng. 2006, 132, 1835-1845.

138. Liu, C.; Yang, L.; Xu, Y. Evolutionary Multiobjective Optimization in Engineering Management: an Empirical Application in Infrastructure Systems. Proceedings of the Sixth International Conference on Intelligent Systems Design and Applications; IEEE: Jinan, China, 2006, Volumn 2, pp. 1006-1011.

139. Lounis, Z. Risk-Based Maintenance Optimization of Aging Highway Bridge Decks. In Advances in Engineering Structures, Mechanics \& Construction; Springer Netherlands: Netherlands, 2006, Volumn 140, pp. 723-734.

140. Madanat, S.; Park, S.; Kuhn, K. Adaptive optimization and systematic probing of infrastructure system maintenance policies under model uncertainty. J. Infrastruct. Syst. 2006, 12, 192-198.

141. Neves, L.; Frangopol, D.; Cruz, P. Probabilistic Lifetime-Oriented Multiobjective Optimization of Bridge Maintenance: single maintenance type. J. Struct. Eng. 2006, 132, 991-1005.

142. Neves, L.A.C.; Frangopol, D.M.; Cruz, P.J.S. Multi-objective probabilistic optimization of bridge lifetime maintenance: novel approach. Proceedings of the International Conference on Bridge Maintenance, Safety and Management, Porto, Portugal, 2006, Volumn 3, pp. 3-11.

143. Robelin, C.A.; Madanat, S.M. Dynamic Programming Based Maintenance and Replacement Optimization for Bridge Decks Using History Dependent Deterioration Models. 9th Int. Conf. Appl. Adv. Technol. Transp. 2006, 13-18.

144. Thompson, M. Multi-objective optimization for bridge management. Proceedings of the 3rd International Conference on Bridge Maintenance, Safety and Management - Bridge Maintenance, Safety, Management, Life-Cycle Performance and Cost, Netherlands, 2006, pp. 1-11.

145. Tsunokawa, K.; Van Hiep, D.; Ul-Islam, R. True Optimization of Pavement Maintenance Options with What-If Models. Comput. Civ. Infrastruct. Eng. 2006, 21, 193-204.

146. Ugwu, O.O.; Kumaraswamy, M.M.; Wong, A.; Ng, S.T. Sustainability appraisal in infrastructure projects (SUSAIP): part 1. development of indicators and computational methods. Autom. Constr. 2006, 15, $239-251$.

147. Yang, S.-I.; Frangopol, D.M.; Kawakami, Y.; Neves, L.C. The use of lifetime functions in the optimization of interventions on existing bridges considering maintenance and failure costs. Reliab. Eng. Syst. Saf. 2006, 91, 698-705.

148. Zecchin, A.C.; Simpson, A.R.; Maier, H.R.; Leonard, M.; Roberts, A.J.; Berrisford, M.J. Application of two ant colony optimisation algorithms to water distribution system optimisation. Math. Comput. Model. 2006, 44, 451-468.

149. Zhang, X. Markov-based optimization model for building facilities management. J. Constr. Eng. Manag. 2006, 132, 1203-1211.

150. Abaza, K. Expected Performance of Pavement Repair Works in a Global Network Optimization Model. J. Infrastruct. Syst. 2007, 13, 124-134.

151. Abaza, K.A.; Murad, M.M. Dynamic probabilistic approach for long-term pavement restoration program with added user cost. Transp. Res. Rec. J. Transp. Res. Board 2007, 1990, 48-56.

152. Babani, J. Development of an asset management plan for municipal water infrastructure, University of Toronto: Toronto, Canada, 2007.

153. Brownlee, T.J.; Finnie, S.; Wightman, D. Identification of potential highways maintenance schemes. Proc. ICE-Transport 2007, 160, 139-146.

154. Dashti, M.A.; Farjami, Y.; Vedadi, A.; Anisseh, M. Implementation of particle swarm optimization in construction of optimal risky portfolios. Proceedings of the 2007 IEEE International Conference on Industrial Engineering and Engineering Management, Singapore, 2007, pp. 812-816.

155. Frangopol, D.; Liu, M. Bridge Network Maintenance Optimization Using Stochastic Dynamic Programming. J. Struct. Eng. 2007, 133, 1772-1782.

156. Frangopol, D.M.; Liu, M. Maintenance and management of civil infrastructure based on condition, safety, optimization, and life-cycle cost. Struct. Infrastruct. Eng. 2007, 3, $29-41$.

157. Hajdin, R.; Lindenmann, H.P. Algorithm for the planning of optimum highway work zones. J. Infrastruct. Syst. 2007, 13, 202-214.

158. Lee, C.-K.; Kim, S.-K. GA-based algorithm for selecting optimal repair and rehabilitation methods for reinforced concrete (RC) bridge decks. Autom. Constr. 2007, 16, 153-164. 
159. Maji, A.; Jha, M.K. Modeling highway infrastructure maintenance schedules with budget constraints. Transp. Res. Rec. J. Transp. Res. Board 2007, 1991, 19-26.

160. Morcous, G. Pareto analysis for multicriteria optimization of bridge preservation decisions. Transp. Res. Rec. J. Transp. Res. Board 2007, 1991, 62-68.

161. Ouyang, Y. Pavement Resurfacing Planning for Highway Networks: Parametric Policy Iteration Approach. J. Infrastruct. Syst. 2007, 13, 65-71.

162. Archondo-Callao, R. Applying the HDM-4 model to strategic planning of road works; World Bank: Washington D.C., USA, 2008.

163. Bako, H.A.; Ambrus-Somogyi, K.; Hartvanyi, T. An Optimal Quality Management Algorithm for Road Maintenance. Proceedings of the International Conference on Intelligent Engineering Systems; IEEE: Miami, USA, 2008, pp. 233-236.

164. Castanier, B.; Yeung, T.G. Optimal highway maintenance policies under uncertainty. Proceedings of the Annual Conference of Reliability and Maintainability Symposium, Las Vega, USA, 2008, pp. 25-30.

165. Dridi, L.M.; Parizeau, M.; Mailhot, A.; Villeneuve, J.P. Using Evolutionary Optimization Techniques for Scheduling Water Pipe Renewal Considering a Short Planning Horizon. Comput. Civ. Infrastruct. Eng. 2008, 23, 625-635.

166. Gao, L.; Zhang, Z. Robust Optimization for Managing Pavement Maintenance and Rehabilitation. Transp. Res. Rec. J. Transp. Res. Board 2008, 2084, 55-61.

167. Halfawy, M.R.; Dridi, L.; Baker, S. Integrated Decision Support System for Optimal Renewal Planning of Sewer Networks. J. Comput. Civ. Eng. 2008, 22, 360-372.

168. Kong, J.; Martin, M.; Moore, I.; Hong, H. Integration of Geographic Information System and Probabilistic Analysis for Optimized Pipe Infrastructure Decisions. Proceedings of the International Pipelines Conferen, Atlanta, USA, 2008, pp. 1-12.

169. Koo, D.H.; Ariaratnam, S.T. Application of a sustainability model for assessing water main replacement options. J. Constr. Eng. Manag. 2008, 134, 563-574.

170. Miyamoto, A.; Uchino, H. Development of life-cycle cost based budget allocation system for bridge group. Proceedings of the 1st International Symposium on Life-Cycle Civil Engineering, Varenna, Italy, 2008, pp. 843-849.

171. Šelih, J.; Kne, A.; Srdić, A.; Žura, M. Multiple-criteria decision support system in highway infrastructure management. Transport 2008, 23, 299-305.

172. Tang, Y.; Chien, S. Scheduling Work Zones for Highway Maintenance Projects: Considering a Discrete Time-Cost Relation. Transp. Res. Rec. J. Transp. Res. Board 2008, 2055, 21-30.

173. Wu, Z.; Flintsch, G.; Chowdhury, T. Hybrid Multiobjective Optimization Model for Regional Pavement-Preservation Resource Allocation. Transp. Res. Rec. J. Transp. Res. Board 2008, 2084, $28-37$.

174. Yare, Y.; Venayagamoorthy, G.K.; Aliyu, U.O. Optimal generator maintenance scheduling using a modified discrete PSO. Gener. Transm. Distrib. IET 2008, 2, 834-846.

175. Abaza, K.A.; Ashur, S.A. Optimum microscopic pavement management model using constrained integer linear programming. Int. J. Pavement Eng. 2009, 10, 149-160.

176. Abiri-Jahromi, A.; Fotuhi-Firuzabad, M.; Abbasi, E. An efficient mixed-integer linear formulation for long-term overhead lines maintenance scheduling in power distribution systems. IEEE Trans. Power Deliv. 2009, 24, 2043-2053.

177. Amador-Jimenez, L.E.; Mrawira, D. Roads performance modeling and management system from two condition data points: case study of Costa Rica. J. Transp. Eng. 2009, 135, 999-1007.

178. Barker, K.; Haimes, Y.Y. Assessing uncertainty in extreme events: applications to risk-based decision making in interdependent infrastructure sectors. Reliab. Eng. Syst. Saf. 2009, 94, 819-829.

179. Dridi, L.; Mailhot, A.; Parizeau, M.; Villeneuve, J. Multiobjective Approach for Pipe Replacement Based on Bayesian Inference of Break Model Parameters. J. Water Resour. Plan. Manag. 2009, 135, 344-354.

180. Farhan, J.; Fwa, T. Pavement Maintenance Prioritization Using Analytic Hierarchy Process. Transp. Res. Rec. J. Transp. Res. Board 2009, 2093, 12-24.

181. Ferreira, A.J.L.; Meneses, S.C.N.; Vicente, F.A.A. Pavement-management system for Oliveira do Hospital, Portugal. Proc. ICE-Transport 2009, 162, 157-169. 
182. Ferreira, A.J.L.; Meneses, S.C.N.; Vicente, F.A.A. Alternative decision-aid tool for pavement management. Proc. ICE-Transport 2009, 162,3-17.

183. Frangopol, D.M.; Okasha, N.M. Multi-criteria optimization of life-cycle performance of structural systems under uncertainty. In Risk and Decision Analysis in Maintenance Optimization and Flood Management; IOS Press BV: Amsterdam, Netherlands, 2009; pp. 99-112.

184. Krueger, D.A.; Garza, J.M. de la Sensitivity analysis of the cost benefit ratio as a function of the level of service targets in the highway maintenance budget allocation process. Proceedings of the International Workshop in Computing in Civil Engineering, American Society of Civil Engineers: Austin, USA, 2009, pp. 308-317.

185. Li, Z. Stochastic optimization model and O (N2) solution algorithm for highway investment decision making under budget uncertainty. J. Transp. Eng. 2009, 135, 371-379.

186. Li, Z.; Madanu, S. Highway Project Level Life-Cycle Benefit/Cost Analysis under Certainty, Risk, and Uncertainty: methodology with case study. J. Transp. Eng. 2009, 135, 516-526.

187. Li, Z.; Sinha, K.C. Application of Shackle's model and system optimization for highway investment decision making under uncertainty. J. Transp. Eng. 2009, 135, 129-139.

188. Orcesi, A.D.; Cremona, C.F. Optimization of management strategies applied to the national reinforced concrete bridge stock in France. Struct. Infrastruct. Eng. 2009, 5, 355-366.

189. Rogers, P.; Grigg, N. Failure Assessment Modeling to Prioritize Water Pipe Renewal: Two Case Studies. J. Infrastruct. Syst. 2009, 15, 162-171.

190. Santos, B.; Antunes, A.; Miller, E. Multiobjective Approach to Long-Term Interurban Multilevel Road Network Planning. J. Transp. Eng. 2009, 135, 640-649.

191. Wu, Z.; Flintsch, G.W. Pavement Preservation Optimization Considering Multiple Objectives and Budget Variability. J. Transp. Eng. 2009, 135, 305-315.

192. Zhang, H. Sustainable pavement asset management based on life cycle models and optimization methods, Ph.D Thesis, University of Michigan: Michigan, USA, 2009.

193. Fan, Y.; Liu, C.; Lee, R.; Kiremidjian, A.S. Highway network retrofit under seismic hazard. J. Infrastruct. Syst. 2009, 16, 181-187.

194. Dabous, S.A.; Alkass, S. A multi-attribute ranking method for bridge management. Eng. Constr. Archit. Manag. 2010, 17, 282-291.

195. Delgado-Galván, X.; Pérez-García, R.; Izquierdo, J.; Mora-Rodríguez, J. An analytic hierarchy process for assessing externalities in water leakage management. Math. Comput. Model. 2010, 52, 1194-1202.

196. Fallah-Fini, S.; Rahmandad, H.; Triantis, K.; de la Garza, J.M. Optimizing highway maintenance operations: dynamic considerations. Syst. Dyn. Rev. 2010, 26, 216-238.

197. Gao, L.; Xie, C.; Zhang, Z. Network-level multi-objective optimal maintenance and rehabilitation scheduling. 89th Annu. Meet. Transp. Res. Board Transp. Res. Board 2010, 1-20.

198. Ge, H. Maintenance optimization for substations with aging equipment, Ph.D Thesis, the University of Nebraska: Nebraska, USA., 2010.

199. Golroo, A.; Mohaymany, A.S.; Mesbah, M. Reliability based investment prioritization in transportation networks. 89th Annu. Meet. Transp. Res. Board Natl. Acad. 2010, 1-14.

200. Gopalakrishnan, K.; Khaitan, S.K. Development of an intelligent pavement analysis toolbox. Proc. ICE Transp. 2010, 163, 211-221.

201. Huang, W.-C.; Teng, J.-Y.; Lin, M.-C. The budget allocation model of public infrastructure projects. J. Mar. Sci. Technol. 2010, 18, 697-708.

202. Jang, W.; Noble, J.S.; Hutsel, T. An integrated model to solve the winter asset and road maintenance problem. IIE Trans. 2010, 42, 675-689.

203. Lukas, K.; Borrmann, A.; Rank, E. Using Ant Colony Optimization for Infrastructure Maintenance Scheduling. Proceedings of the European Conference on Product and Process Modelling, CRC Press: Vienna, 2010; pp. 371-375.

204. Meneses, S.; Ferreira, A. Multi-objective decision-aid tool for pavement management systems. Proceedings of the 12th World conference on transport research, Lisbon, Portugal, 2010, Volumn 166, pp. 79-94. 
205. Morais, D.C.; Almeida, A.T. Water network rehabilitation: a group decision-making approach. Water $S A$ 2010, 36, 487-493.

206. Mouratidis, A.; Papageorgiou, G. A rational approach for optimization of road upgrading. Can. J. Civ. Eng. 2010, 37, 1462-1470.

207. Nafi, A.; Kleiner, Y. Scheduling renewal of water pipes while considering adjacency of infrastructure works and economies of scale. J. Water Resour. Plan. Manag. 2009, 136, 519-530.

208. Nyström, B.; Söderholm, P. Selection of maintenance actions using the analytic hierarchy process (AHP): decision-making in railway infrastructure. Struct. Infrastruct. Eng. 2010, 6, 467-479.

209. Okasha, N.; Frangopol, D. Novel Approach for Multicriteria Optimization of Life-Cycle Preventive and Essential Maintenance of Deteriorating Structures. J. Struct. Eng. 2010, 136, 1009-1022.

210. Orcesi, A.D.; Cremona, C.F. A bridge network maintenance framework for Pareto optimization of stakeholders/users costs. Reliab. Eng. Syst. Saf. 2010, 95, 1230-1243.

211. Orcesi, A.D.; Frangopol, D.M.; Kim, S. Optimization of bridge maintenance strategies based on multiple limit states and monitoring. Eng. Struct. 2010, 32, 627-640.

212. Orcesi, A.D.; Cremona, C.F. Optimization of maintenance strategies for the management of the national bridge stock in France. J. Bridg. Eng. 2010, 16, 44-52.

213. Ozbek, M.; Garza, J. de la; Triantis, K. Data and Modeling Issues Faced during the Efficiency Measurement of Road Maintenance Using Data Envelopment Analysis. J. Infrastruct. Syst. 2010, 16, 21-30.

214. Petreska, B.R.; Kolemisevska-Gugulovska, T.D. A fuzzy rate-of-return based model for portfolio selection and risk estimation. Proceedings of the IEEE International Conference on Systems, Man and Cybernetics, Istanbul, Turkey, 2010, pp. 1871-1877.

215. Scheinberg, T.; Anastasopoulos, P.C. Pavement preservation programming: a multi-year multi-constraint optimization methodology. Proceedings of the 89th Annual Meeting of the Transportation Research Board, Washington, D.C. USA, 2010, pp. 1-16.

216. Seidl, W.; Cypra, T. Maintenance Decision Support System (MDSS) ASFINAG / Austria. In Data and Mobility; Düh, J., Hufnagl, H., Juritsch, E., Pfliegl, R., Schimany, H.-K., Schönegger, H., Springer Berlin Heidelberg: Heidelberg, German, 2010; Volume 81, pp. 139-150.

217. Shahata, K.; Zayed, T. Integrated decision-support framework for municipal infrastructure asset. Proceedings of the Pipelines 2010: Climbing New Peaks to Infrastructure Reliability - Renew, Rehab, \& Reinvest, Keystone, USA, 2010, pp. 1492-1502.

218. Sharma, V. Asset Levels of Service-based decision support system for municipal infrastructure investment, University of Alberta: Alberta, Canada, 2010.

219. Sirvio, K.; Hollmén, J. Multi-year network level road maintenance programming by genetic algorithms and variable neighbourhood search. Proceedings of the Multi-year network level road maintenance programming by genetic algorithms and variable neighbourhood search Intelligent Transportation Systems (ITSC), Funchal, Portugal, 2010, pp. 581-586.

220. Sun, L.; Gu, W. Pavement condition assessment using fuzzy logic theory and analytic hierarchy process. J. Transp. Eng. 2010, 137, 648-655.

221. Thompson, M.; Sessions, J.; Boston, K.; Skaugset, A.; Tomberlin, D. Forest Road Erosion Control Using Multiobjective Optimization. J. Am. Water Resour. Assoc. 2010, 46, 712-723.

222. Weber, T.C.; Allen, W.L. Beyond on-site mitigation: an integrated, multi-scale approach to environmental mitigation and stewardship for transportation projects. Landsc. Urban Plan. 2010, 96, 240-256.

223. Zhu, S.; Lu, J. Evaluation index and methods of highway intersection safety maintenance. Proceedings of the International Chinese Conference of Transportation Professionals (ICCTP) 2010: Integrated Transportation Systems-Green, Intelligent, Reliable, Beijing, China, 2010, pp. 971-976.

224. Augeri, M.; Colombrita, R.; Greco, S.; Certo, A. Lo; Matarazzo, B.; Slowinski, R. Dominance-Based Rough Set Approach to Budget Allocation in Highway Maintenance Activities. J. Infrastruct. Syst. 2011, 17, 75-85.

225. Bocchini, P.; Frangopol, D.M. Probabilistic bridge network life-cycle connectivity assessment and optimization. In Applications of Statistics and Probability in Civil Engineering, Taylor \& Francis Group: London, UK, 2011; pp. 160-161. 
226. Bocchini, P.; Frangopol, D.M. A probabilistic computational framework for bridge network optimal maintenance scheduling. Reliab. Eng. Syst. Saf. 2011, 96, 332-349.

227. Cafiso, S.; Graziano, A. Di Surrogate Safety Measures for Optimizing Investments in Local Rural Road Networks. Transp. Res. Rec. J. Transp. Res. Board 2011, 2237, 20-30.

228. Durán, O. Computer-aided maintenance management systems selection based on a fuzzy AHP approach. Adv. Eng. Softw. 2011, 42, 821-829.

229. Enevoldsen, I. Practical implementation of probability based assessment methods for bridges. Struct. Infrastruct. Eng. 2011, 7, 535-549.

230. Furuta, H.; Frangopol, D.M.; Nakatsu, K. Life-cycle cost of civil infrastructure with emphasis on balancing structural performance and seismic risk of road network. Struct. Infrastruct. Eng. 2011, 7, 65-74.

231. Gao, L.; Xie, C.; Zhang, Z.; Waller, S.T. Integrated Maintenance and Expansion Planning for Transportation Network Infrastructure. Transp. Res. Rec. J. Transp. Res. Board 2011, 2225, 56-64.

232. Jesus, M.; Akyildiz, S.; Bish, D.R.; Krueger, D.A. Network-level optimization of pavement maintenance renewal strategies. Adv. Eng. Informatics 2011, 25, 699-712.

233. Lee, S.Y.; Park, W.; Ok, S.Y.; Koh, H.M. Preference-based maintenance planning for deteriorating bridges under multi-objective optimisation framework. Struct. Infrastruct. Eng. 2011, 7, 633-644.

234. Li, H.; Huang, X.; Feng, Q. Optimizing expressway maintenance planning by coupling ant algorithm and geography information system transportation in Hubei province, China. Proceedings of the 2011 IEEE International Conference on Geoscience and Remote Sensing Symposium, Vancouver, Canada, 2011, pp. 2977-2979.

235. Lin, K.L.; Lin, C.L. Applying Utility Theory to Cost Allocation of Pavement Maintenance and Repair. Int. J. Pavement Res. Technol. 2011, 4, 212-221.

236. Lukas, K.; Borrmann, A. Minimizing the traffic impact caused by infrastructure maintenance using ant colony optimization. Proceedings of the 28th International Conference on Automation and Robotics in Construction, Seoul, Korea, 2011, pp. 1002-1006.

237. Sathaye, N.; Madanat, S. A bottom-up solution for the multi-facility optimal pavement resurfacing problem. Transp. Res. Part B Methodol. 2011, 45, 1004-1017.

238. McDonald, M.; Madanat, S. Life-cycle cost minimization and sensitivity analysis for mechanistic-empirical pavement design. J. Transp. Eng. 2011, 138, 706-713.

239. Ng, M.; Zhang, Z.; Travis Waller, S. The price of uncertainty in pavement infrastructure management planning: An integer programming approach. Transp. Res. Part C Emerg. Technol. 2011, 19, 1326-1338.

240. Orabi, W.; El-Rayes, K. Maximizing Rehabilitation Benefits of Aging Transportation Networks. Proceedings of the the 3rd International/9th Construction Specialty Conference, Ottawa, Canada, 2011, pp. 14-17.

241. Orabi, W.; El-Rayes, K. Optimizing the rehabilitation efforts of aging transportation networks. J. Constr. Eng. Manag. 2011, 138, 529-539.

242. Orcesi, A.D.; Frangopol, D.M. A stakeholder probability-based optimization approach for cost-effective bridge management under financial constraints. Eng. Struct. 2011, 33, 1439-1449.

243. Orcesi, A.D.; Frangopol, D.M. Optimization of bridge maintenance strategies based on structural health monitoring information. Struct. Saf. 2011, 33, 26-41.

244. Orcesi, A.; Frangopol, D. Probability-based multiple-criteria optimization of bridge maintenance using monitoring and expected error in the decision process. Struct. Multidiscip. Optim. 2011, 44, 137-148.

245. Santos, J.; Ferreira, A. Pavement Design Optimization Considering Costs and Preventive Interventions. J. Transp. Eng. 2011, 138, 911-923.

246. Tee, K.F.; Li, C.Q. A numerical study of maintenance strategy for concrete structures in marine environment. Proceedings of the 11th International Conference on Applications of Statistics and Probability in Civil Engineering, Zurich, Switzerland, 2011, pp. 618-625.

247. Xue-zhen, D.; Lei, X.; Bo, Z. Research on Intelligence Decision-Making Analysis and Optimization Design Development of Pavement Management System. In Applied Informatics and Communication; Springer Berlin Heidelberg: Heidelberg, German, 2011; Volume 224, pp. 682-690.

248. Yang, Y.N.; Kumaraswamy, M.M. Towards life-cycle focused infrastructure maintenance for concrete bridges. Facilities 2011, 29, 577-590. 
249. Adey, B.T.; Herrmann, T.; Tsafatinos, K.; Lüking, J.; Schindele, N.; Hajdin, R. Methodology and base cost models to determine the total benefits of preservation interventions on road sections in Switzerland. Struct. Infrastruct. Eng. 2012, 8, 639-654.

250. Bocchini, P.; Frangopol, D. Optimal Resilience- and Cost-Based Postdisaster Intervention Prioritization for Bridges along a Highway Segment. J. Bridg. Eng. 2012, 17, 117-129.

251. Bai, Q.; Labi, S.; Sinha, K.C. Trade-Off Analysis for Multiobjective Optimization in Transportation Asset Management by Generating Pareto Frontiers Using Extreme Points Nondominated Sorting Genetic Algorithm II. J. Transp. Eng. 2012, 138, 798-808.

252. Chou, E.Y.; Wang, S. Benefit Cost Models to Support Pavement Management Decisions; Ohio Department of Transportation: Toledo, Canada, 2012.

253. Essahli, Z.; Madanat, S. Optimal Allocation of Resources to Maintain, Rehabilitate, and Reconstruct Heterogeneous Bridge Networks. Transp. Res. Rec. J. Transp. Res. Board 2012, 2292, 134-140.

254. Farran, M.; Zayed, T. New life-cycle costing approach for infrastructure rehabilitation. Eng. Constr. Archit. Manag. 2012, 19, 40-60.

255. Fwa, T.F.; Farhan, J. Optimal multiasset maintenance budget allocation in Highway asset management. J. Transp. Eng. 2012, 138, 1179-1187.

256. Gervásio, H.; Silva, L.S. da A probabilistic decision-making approach for the sustainable assessment of infrastructures. Expert Syst. Appl. 2012, 39, 7121-7131.

257. Jorge, D.; Ferreira, A. Road network pavement maintenance optimisation using the HDM-4 pavement performance prediction models. Int. J. Pavement Eng. 2012, 13, 39-51.

258. Lertworawanich, P. Highway network restoration after the great flood in Thailand. Nat. Hazards 2012, 64, 873-886.

259. Marlow, D.R.; Beale, D.J.; Mashford, J.S. Risk-based prioritization and its application to inspection of valves in the water sector. Reliab. Eng. Syst. Saf. 2012, 100, 67-74.

260. Medury, A.; Madanat, S.M. System-Level Optimization of Maintenance and Replacement Decisions for Road Networks. Appl. Stat. Probab. Civ. Eng. 2012, 29, 235-242.

261. Okeola, O.G.; Sule, B.F. Evaluation of management alternatives for urban water supply system using Multicriteria Decision Analysis. J. King Saud Univ. - Eng. Sci. 2012, 24, 19-24.

262. Ward, B.; Savic, D. A multi-objective optimisation model for sewer rehabilitation considering critical risk of failure. Water Sci. Technol. 2012, 66, 2410-2417.

263. Xie, X.R. The Study on Maintenance Mechanism of Rural Highway in China. Adv. Mater. Res. 2012, 403-408, 2915-2918.

264. Yadollahi, M.; Zin, R.M. Multi-strategy budget allocation decision support system for seismic rehabilitation of road infrastructure. Struct. Infrastruct. Eng. 2012, 10, 239-260.

265. Zhang, X.; Gao, H. Road maintenance optimization through a discrete-time semi-Markov decision process. Reliab. Eng. Syst. Saf. 2012, 103, 110-119.

266. Almeida, J.O.; Teixeira, P.F.; Delgado, R.M. Life cycle cost optimisation in highway concrete bridges management. Struct. Infrastruct. Eng. 2013, 10, 1263-1276.

267. Amador-Jiménez, L.E.; Afghari, A.P. Non-monetised multi-objective decision making system for road management. Int. J. Pavement Eng. 2013, 14, 686-696.

268. Barone, G.; Frangopol, D.M.; Soliman, M. Optimization of Life-Cycle Maintenance of Deteriorating Bridges with Respect to Expected Annual System Failure Rate and Expected Cumulative Cost. J. Struct. Eng. 2013, 140, 1-13.

269. Gao, H.; Zhang, X. A Markov-Based Road Maintenance Optimization Model Considering User Costs. Comput. Civ. Infrastruct. Eng. 2013, 28, 451-464.

270. Gao, L.; Guo, R.; Zhang, Z. An augmented Lagrangian decomposition approach for infrastructure maintenance and rehabilitation decisions under budget uncertainty. Struct. Infrastruct. Eng. 2013, 9, 448-457.

271. Kleiner, Y. Simultaneous Optimization of Pipe and Pavement Renewal Scheduling. Proceedings of the World Environmental and Water Resources Congress, American Society of Civil Engineers: Cincinnati, USA, 2013, pp. 967-974. 
272. Lambert, J.; Wu, Y.; You, H.; Clarens, A.; Smith, B. Climate Change Influence on Priority Setting for Transportation Infrastructure Assets. J. Infrastruct. Syst. 2013, 19, 36-46.

273. Liang, S.; Wey, W.M. Resource allocation and uncertainty in transportation infrastructure planning: a study of highway improvement program in Taiwan. Habitat Int. 2013, 39, 128-136.

274. Meneses, S.; Ferreira, A. Pavement maintenance programming considering two objectives: maintenance costs and user costs. Int. J. Pavement Eng. 2013, 14, 206-221.

275. Salem, O.M.; Miller, R.A.; Deshpande, A.S.; Arurkar, T.P. Multi-criteria decision-making system for selecting an effective plan for bridge rehabilitation. Struct. Infrastruct. Eng. 2013, 9, 806-816.

276. Santos, J.; Ferreira, A. Life-cycle cost analysis system for pavement management at project level. Int. J. Pavement Eng. 2013, 14, 71-84.

277. Adey, B.T.; Lethanh, N.; Hartmann, A.; Viti, F. Evaluation of intervention strategies for a road link in the Netherlands. Built Environ. Proj. asset Manag. 2014, 4, 180-198.

278. Anastasopoulos, P.; Haddock, J.; Peeta, S. Improving Systemwide Sustainability in Pavement Preservation Programming. J. Transp. Eng. 2014, 140, 4-13.

279. Charmpis, D.; Dimitriou, L.; Balafas, I.; Alogdianakis, F. Optimal Bridges' Upgrade Programming under Technical, Economical and Social Considerations. Proceedings of the International Conference on Engineering and Applied Sciences Optimization, Kos Island, Greece, 2014, pp. 1-12.

280. Galenko, A.; Garvey, J.; Scheinberg, T. Pavement Analyst ${ }^{\mathrm{TM}}$ : Theoretical models and practical applications. Proceedings of the International Conference on Engineering and Applied Sciences Optimization, Kos Island, Greece, 2014, pp. 1-8.

281. Khan, M.U.; Mesbah, M.; Ferreira, L.; Williams, D.J. Development of road deterioration models incorporating flooding for optimum maintenance and rehabilitation strategies. Road Transp. Res. A J. Aust. New Zeal. Res. Pract. 2014, 23, 3-24.

282. Lee, J.; Madanat, S. Joint optimization of pavement design, resurfacing and maintenance strategies with history-dependent deterioration models. Transp. Res. Part B Methodol. 2014, 68, 141-153.

283. Lethanh, N.; Adey, B.T.; Fernando, D.N. Optimal intervention strategies for multiple objects affected by manifest and latent deterioration processes. Struct. Infrastruct. Eng. 2014, 11, 389-401.

284. Liu, H.; Madanat, S. Adaptive optimisation methods in system-level bridge management. Struct. Infrastruct. Eng. 2014, 11, 884-896.

285. Lwambuka, L.; Mtenga, P. V Bridge Management Strategy Based on Extreme User Costs for Bridge Network Condition. Adv. Civ. Eng. 2014, 2014, 390359.

286. Rashedi, R.; Hegazy, T. Capital renewal optimisation for large-scale infrastructure networks: genetic algorithms versus advanced mathematical tools. Struct. Infrastruct. Eng. 2014, 11, 253-262.

287. Zhang, W.; Wang, W. Cost modelling in maintenance strategy optimisation for infrastructure assets with limited data. Reliab. Eng. Syst. Saf. 2014, 130, 33-41.

288. Chen, L.; Henning, T.F.P.; Raith, A.; Shamseldin, A.Y. Multiobjective Optimization for Maintenance Decision Making in Infrastructure Asset Management. J. Manag. Eng. 2015, 31, 04015015.

289. Fallah-Fini, S.; Triantis, K.; Rahmandad, H.; de la Garza, J.M. Measuring dynamic efficiency of highway maintenance operations. Omega 2015, 50, 18-28.

290. Farran, M.; Zayed, T. Fitness-oriented multi-objective optimisation for infrastructures rehabilitations. Struct. Infrastruct. Eng. 2015, 11, 1-15.

291. Jovanovic, S.; Bozovic, D. Optimal Structure and Two Case Study Implementations of a Railway Maintenance Management System. J. Manag. Eng. 2015, 31, 5-14.

292. Lee, J.; Madanat, S. A joint bottom-up solution methodology for system-level pavement rehabilitation and reconstruction. Transp. Res. Part B Methodol. 2015, 78, 106-122.

293. Osman, H. Coordination of urban infrastructure reconstruction projects. Struct. Infrastruct. Eng. 2015, 12, 1-14.

294. Saad, D.A.; Hegazy, T. Behavioral Economic Concepts for Funding Infrastructure Rehabilitation. J. Manag. Eng. 2015, 31, 04014089.1-9.

295. Rokstad, M.M.; Ugarelli, R.M. Minimising the total cost of renewal and risk of water infrastructure assets by grouping renewal interventions. Reliab. Eng. Syst. Saf. 2015, 142, 148-160. 
296. Weninger-Vycudil, A.; Hanley, C.; Deix, S.; O'Connor, A.; Pakrashi, V. Cross-asset management for road infrastructure networks. Proc. Inst. Civ. Eng. 2015, 168, 442-456.

297. Yadollahi, M.; Majid, M.Z.A.; Zin, R.M. Post-Pareto optimality approach to enhance budget allocation process for bridge rehabilitation management. Struct. Infrastruct. Eng. 2015, 11, 1565-1582.

298. Abronzini, U.; Attaianese, C.; D’Arpino, M.; Di Monaco, M.; Genovese, A.; Pede, G.; Tomasso, G. Optimal energy control for smart charging infrastructures with ESS and REG. Proceedings of the 2016 International Conference on Electrical Systems for Aircraft, Railway, Ship Propulsion and Road Vehicles \& International Transportation Electrification Conference, Toulouse, France, 2016, pp. 1-16.

299. Amin, M.S.R.; Amador-Jimenez, L.E. Pavement management with dynamic traffic and artificial neural network: a case study of Montreal. Can. J. Civ. Eng. 2016, 43, 241-251.

300. Alves, A.; Sanchez Torres, A.; Vojinovic, Z.; Seyoum, S.; Babel, M.; Brdjanovic, D. Evolutionary and Holistic Assessment of Green-Grey Infrastructure for CSO Reduction. Water 2016, 8, 402.

301. Bai, W.; Liu, R.; Sun, Q.; Wang, F.; Xu, P. A stochastic model for the estimation of renewal periods of sharply curved metro rails. Proc. Inst. Mech. Eng. Part F J. Rail Rapid Transit 2016, 232.

302. Guler, H. Optimisation of railway track maintenance and renewal works by genetic algorithms. J. Croat. Assoc. Civ. Eng. 2016, 68, 979-993.

303. Khan, M.U.; Mesbah, M.; Ferreira, L.; Williams, D.J. Development of optimum pavement maintenance strategies for a road network. Aust. J. Civ. Eng. 2016, 14, 85-96.

304. Laumet, P.; Bruun, M. Trade-off analysis for infrastructure management: new approaches to cross-asset challenges. Proceedings of the 6th Transport Research Arena; Warsaw, Poland, 2016, pp. 422-429.

305. Lee, J.; Madanat, S.; Reger, D. Pavement systems reconstruction and resurfacing policies for minimization of life-cycle costs under greenhouse gas emissions constraints. Transp. Res. Part B Methodol. 2016, 93, 618-630.

306. Lethanh, N.; Adey, B.T. A real option approach to determine optimal intervention windows for multi-national rail corridors. J. Civ. Eng. Manag. 2016, 22, 38-46.

307. Orcesi, A.D.; Chemineau, H.; Lin, P.-H.; van Gelder, P.; van Erp, N. A risk analysis for asset management considering climate change. Proceedings of the 6th Transport Research Arena, Warsaw, Poland, 2016, pp. 105-114.

308. Saha, P.; Ksaibati, K. A risk-based optimisation methodology for pavement management system of county roads. Int. J. Pavement Eng. 2016, 17, 913-923.

309. Irfan Rifai, A.; Hadiwardoyo, S.P.; Gomes Correia, A.; Pereira, P. Genetic Algorithm Applied for Optimization of Pavement Maintenance under Overload Traffic: Case Study Indonesia National Highway. Appl. Mech. Mater. 2016, 845, 369-378.

310. Rolik, O.; Kolesnik, V.; Halushko, D. Decomposition-compensation method of service level management in corporate IT infrastructures with the use of adaptive genetic algorithm. Proceedings of the 2016 International Conference Radio Electronics \& Info Communications, Kiev, Ukraine, 2016, pp. 1-5.

311. Shoghli, O.; Garza, J.M. A Multi-Objective Decision-Making Approach for the Sustainable Maintenance of Roadways. Proceedings of the Construction Research Congress, San Juan, Puerto Rico, 2016, pp. 1424-1434.

312. Diego Porras-Alvarado, J.; Han, Z.; Al-Amin, M.; Zhang, Z. Fairness and Efficiency Considerations in Performance-Based, Cross-Asset Resource Allocation. J. Transp. Res. Rec. 2016, 19-27.

313. Yepes, V.; Torres-Machi, C.; Chamorro, A.; Pellicer, E. Optimal pavement maintenance programs based on a hybrid greedy randomized adaptive search procedure algorithm. J. Civ. Eng. Manag. 2016, 22, 540-550.

314. Denysiuk, R.; Moreira, A. V; Matos, J.C.; Oliveira, J.R.M.; Santos, A. Two-Stage Multiobjective Optimization of Maintenance Scheduling for Pavements. J. Infrastruct. Syst. 2017, 23, 04017001.

315. Gaspar, L. Management aspects of road pavement rehabilitation. Gradevinar 2017, 1, 31-40.

316. Hamdi, P.; Hadiwardoyo, S.P.; Correia, A.G.; Pereira, P. New optimization strategies of pavement maintenance: a case study for national road network in Indonesia using integrated Road Management System. Proceedings of the 3rd International Conference on Engineering, Technology, and Industrial Application (ICETIA), Surakarta, Indonesia, 2016, pp. 2919-2924.

317. Khan, M.U.; Mesbah, M.; Ferreira, L.; Williams, D.J. Development of a post-flood road maintenance strategy: case study Queensland, Australia. Int. J. Pavement Eng. 2017, 18, 702-713.

318. Khadka, M. Comprehensive Clusterwise Linear Regression for Pavement Management Systems; 2017. 
319. Kitaha, A.; Biligiri, K.P. Prioritization-Optimization Process Algorithm to Manage Pavement Networks During the Non-Availability of Historical Data. J. Test. Eval. 2017, 45, 546-563.

320. Lee, J.; Madanat, S. Optimal policies for greenhouse gas emission minimization under multiple agency budget constraints in pavement management. Transp. Res. Part D Transp. Environ. 2017, 55, 39-50.

321. Marzouk, M.; Osama, A. Fuzzy-Based Methodology for Integrated Infrastructure Asset Management. Int. J. Comput. Intell. Syst. 2017, 10, 745-759.

322. Mandiartha, P.; Duffield, C.F.; Razelan, I.S.B.M.; Ismail, A.B.H. Pavement maintenance optimization model using Markov Decision Processes. Proceedings of the 1st International Conference on Applied and Industrial Mathematics and Statistics, Kuantan, Malaysia, 2017, pp. 012104.

323. Moreira, A.V.; Fwa, T.F.; Oliveira, J.R.M.; Costa, L. Coordination of User and Agency Costs Using Two-Level Approach for Pavement ManagementOptimization. J. Transp. Res. Rec. 2017, 110-118.

324. Fatemeh, N.; Mohamadhossein, N.; Bo, Z.; Kouros, M.A. Optimal Facility-Specific Inspection and Maintenance Decisions under Measurement Uncertainty: Unifying Framework. J. Infrastruct. Syst. 2017, 23, 4017036.

325. Ramachandran, S.; Rajendran, C.; Veeraragavan, A.; Ramya, R. A framework for maintenance management of pavement networks under performance-based Multi-Objective Optimization. Proceedings of the Airfielf and Highway Pavement 2017: Design, Construction, Evaluation, and Management of Pavements, Philadelphia, USA, 2017, pp. 209-221.

326. Saad, D.; Hegazy, T. Economic optimization for the rehabilitation of co-located mixed assets; 2017; Vol. 44.

327. Santos, J.; Ferreira, A.; Flintsch, G. An adaptive hybrid genetic algorithm for pavement management. Int. J. Pavement Eng. 2017, 1-21.

328. Shoghli, O.; de la Garza, J. Multi-Asset Optimization of Roadways Asset Maintenance. Proceedings of the ASCE International Workshop on Computing in Civil Engineering, 2017, pp. 297-305.

329. Su, Z.; Jamshidi, A.; Núñez, A.; Baldi, S.; De Schutter, B. Multi-level condition-based maintenance planning for railway infrastructures - A scenario-based chance-constrained approach. Transp. Res. Part C Emerg. Technol. 2017, 84, 92-123.

330. Torres-Machi, C.; Pellicer, E.; Yepes, V.; Chamorro, A. Towards a sustainable optimization of pavement maintenance programs under budgetary restrictions. J. Clean. Prod. 2017, 148, 90-102.

331. van Riel, W.; Post, J.; Langeveld, J.; Herder, P.; Clemens, F. A gaming approach to networked infrastructure management. Struct. Infrastruct. Eng. 2017, 13, 855-868.

332. Yoon, Y.; Hastak, M. Multitiered prioritizing method using urgency scale for bridge deck rehabilitation. J. Infrastruct. Syst. 2017, 23.

333. Zhang, L.; Fu, L.L.; Gu, W.H.; Ouyang, Y.F.; Hu, Y.H. A general iterative approach for the system-level joint optimization of pavement maintenance, rehabilitation, and reconstruction planning. Transp. Res. Part B Methodol. 2017, 105, 378-400.

334. Abaza, K.A. Optimal Empirical-Markovian approach for assessment of potential pavement rehabilitation strategies at the project level. Road Mater. Pavement Des. 2018, 19, 646-667.

335. Abu Samra, S.; Ahmed, M.; Hammad, A.; Zayed, T. Multiobjective framework for managing municipal integrated infrastructure. J. Constr. Eng. Manag. 2018, 144, 04017091.

336. Bako, A.; Gaspar, L. Development of a Sustainable Optimization Model for the Rehabilitation of Transport Infrastructure. Acta Polytech. Hungarica 2018, 15, 11-33.

337. France-Mensah, J.; O’Brien, W.J. Budget Allocation Models for Pavement Maintenance and Rehabilitation: Comparative Case Study. J. Manag. Eng. 2018, 24, 05018002.

\section{References}

1. Marlow, D.R.; Beale, D.J.; Burn, S. A pathway to a more sustainable water sector: Sustainability-based asset management. Water Sci. Technol. 2010, 61, 1245-1255. [CrossRef]

2. Too, E.G.; Too, L. Strategic infrastructure asset management: A conceptual framework to identify capabilities. J. Corp. Real Estate 2010, 12, 196-208. [CrossRef] 
3. Schraven, D.F.J.; Hartmann, A.; Dewulf, G.P.M.R. Research orientations towards the 'management' of infrastructure assets: An intellectual structure approach AU-Schraven, Daan F.J. Struct. Infrastruct. Eng. 2015, 11, 73-96. [CrossRef]

4. NAMS. International Infrastructure Management Manual; Byrne, R., Hughes, A., Eds.; National Asset Management Support Group: Wellington, New Zealand, 2011; ISBN 0-473-10685-X.

5. Sinha, S.K.; Eslambolchi, S.S. Bridging the Gap: An Educational Primer on Sustainable Water Infrastructure Asset Management; Pennsylvania State University: State College, PA, USA, 2006.

6. Austroad. Guide to Asset Management-Overview Part 1: Introduction, 3rd ed.; Austroad: Sydney, Australlia, 2018.

7. Bai, Q.; Labi, S.; Sinha, K.C. Trade-Off Analysis for Multiobjective Optimization in Transportation Asset Management by Generating Pareto Frontiers Using Extreme Points Nondominated Sorting Genetic Algorithm II. J. Transp. Eng. 2012, 138, 798-808. [CrossRef]

8. Chen, L. Development of a Multi-Objective Optimisation Technique for Long-Term and Network-Level Decision Making in Infrastructure Asset Management. Ph.D. Thesis, The University of Auckland, Auckland, New Zealand, 2016.

9. Hillier, F.S.; Lieberman, G.J. Introduction to Operations Research, 8th ed.; Elizabeth A. Jones: New York, NY, USA, 2005; ISBN 0-07-252744-7.

10. Maunsell Limited. Optimised Decision Making Guidelines: A Sustainable Approach to Managing Infrastructure, 1.0.; NZ National Asset Management Steering Group: Wellington, New Zealand, 2004.

11. Sharma, V. Asset Levels of Service-Based Decision Support System for Municipal Infrastructure Investment; University of Alberta: Edmonton, AB, Canada, 2010.

12. Abelson, P.W.; Flowerdew, A.D.J. Models for the economic evaluation of road Maintenance. J. Transp. Econ. Policy 1975, 4, 93-114.

13. Way, G.B. Network optimization system for Arizona. In Proceedings of the 1st North American Pavement Management Conference, Toronto, ON, Canada, 18-21 March 1985; pp. 16-22.

14. Flintsch, G.W.; Chen, C. Soft computing applications in infrastructure management. J. Infrastruct. Syst. 2004, 10, 157-166. [CrossRef]

15. American Federal Highway Administration. Asset Management Primer; Federal Highway Administration: Washington, DC, USA, 1999.

16. Bai, Q. Trade-Off Analysis in Multiobjective Optimization for Transportation Asset Management. Ph.D. Thesis, Purdue University, West Lafayette, IN, USA, 2012.

17. Deighton-Official Site. Available online: https://www.deighton.com (accessed on 10 January 2019).

18. Infrastructure Asset Management Software and Services. Available online: https://www.aldensys.com (accessed on 10 January 2019).

19. Top infrastructure Asset Management Software in Delhi, India. Available online: http://www.tappetbox. com/ (accessed on 10 January 2019).

20. Infrastructure Management Software I Pitney Bowes. Available online: https://www.aldensys.com (accessed on 10 January 2019).

21. Yoon, Y.; Hastak, M. Multitiered prioritizing method using urgency scale for bridge deck rehabilitation. J. Infrastruct. Syst. 2017, 23. [CrossRef]

22. Alves, A.; Sanchez Torres, A.; Vojinovic, Z.; Seyoum, S.; Babel, M.; Brdjanovic, D. Evolutionary and Holistic Assessment of Green-Grey Infrastructure for CSO Reduction. Water 2016, 8, 402. [CrossRef]

23. Abronzini, U.; Attaianese, C.; D’Arpino, M.; Di Monaco, M.; Genovese, A.; Pede, G.; Tomasso, G. Optimal energy control for smart charging infrastructures with ESS and REG. In Proceedings of the 2016 International Conference on Electrical Systems for Aircraft, Railway, Ship Propulsion and Road Vehicles \& International Transportation Electrification Conference, Toulouse, France, 2-4 November 2016; pp. 1-16.

24. Abu Samra, S.; Ahmed, M.; Hammad, A.; Zayed, T. Multiobjective framework for managing municipal integrated infrastructure. J. Constr. Eng. Manag. 2018, 144, 04017091. [CrossRef]

25. Shoghli, O.; Garza, J.M. A Multi-Objective Decision-Making Approach for the Sustainable Maintenance of Roadways. In Proceedings of the Construction Research Congress, San Juan, Puerto Rico, 31 May-2 June 2016; pp. 1424-1434.

26. Lee, J.; Madanat, S. A joint bottom-up solution methodology for system-level pavement rehabilitation and reconstruction. Transp. Res. Part B Methodol. 2015, 78, 106-122. [CrossRef] 
27. Santos, J.; Ferreira, A. Life-cycle cost analysis system for pavement management at project level. Int. J. Pavement Eng. 2013, 14, 71-84. [CrossRef]

28. Zhang, L.; Fu, L.L.; Gu, W.H.; Ouyang, Y.F.; Hu, Y.H. A general iterative approach for the system-level joint optimization of pavement maintenance, rehabilitation, and reconstruction planning. Transp. Res. Part B Methodol. 2017, 105, 378-400. [CrossRef]

29. Jesus, M.; Akyildiz, S.; Bish, D.R.; Krueger, D.A. Network-level optimization of pavement maintenance renewal strategies. Adv. Eng. Inform. 2011, 25, 699-712.

30. Rashedi, R.; Hegazy, T. Capital renewal optimisation for large-scale infrastructure networks: Genetic algorithms versus advanced mathematical tools. Struct. Infrastruct. Eng. 2014, 11, 253-262. [CrossRef]

31. Abaza, K.A.; Ashur, S.A. Optimum microscopic pavement management model using constrained integer linear programming. Int. J. Pavement Eng. 2009, 10, 149-160. [CrossRef]

32. Saad, D.A.; Hegazy, T. Behavioral Economic Concepts for Funding Infrastructure Rehabilitation. J. Manag. Eng. 2015, 31, 04014089. [CrossRef]

33. Fallah-Fini, S.; Triantis, K.; Rahmandad, H.; de la Garza, J.M. Measuring dynamic efficiency of highway maintenance operations. Omega 2015, 50, 18-28. [CrossRef]

34. Alyami, Z.; Tighe, S.L. Project Asset Management for Pavement Assets under Performance-Based Contracts. In Proceedings of the Second International Conference on Public-Private Partnerships, Austin, TX, USA, 26-29 May 2015; pp. 211-224.

35. Hamdi, P.; Hadiwardoyo, S.P.; Correia, A.G.; Pereira, P. New optimization strategies of pavement maintenance: A case study for national road network in Indonesia using integrated Road Management System. In Proceedings of the 3rd International Conference on Engineering, Technology, and Industrial Application (ICETIA); AIP Publishing LLC: Surakarta, Indonesia, 2016; pp. 2919-2924.

36. Wu, D.Y.; Yuan, C.W.; Liu, H.C. A risk-based optimisation for pavement preventative maintenance with probabilistic LCCA: A Chinese case. Int. J. Pavement Eng. 2017, 18, 11-25. [CrossRef]

37. Lee, J.; Madanat, S.; Reger, D. Pavement systems reconstruction and resurfacing policies for minimization of life-cycle costs under greenhouse gas emissions constraints. Transp. Res. Part B Methodol. 2016, 93, 618-630. [CrossRef]

38. Lee, J.; Madanat, S. Joint optimization of pavement design, resurfacing and maintenance strategies with history-dependent deterioration models. Transp. Res. Part B Methodol. 2014, 68, 141-153. [CrossRef]

39. Mandiartha, P.; Duffield, C.F.; Thompson, R.G.; Wigan, M.R. Measuring pavement maintenance effectiveness using Markov Chains analysis. Struct. Infrastruct. Eng. 2017, 13, 844-854. [CrossRef]

40. Diego Porras-Alvarado, J.; Han, Z.; Al-Amin, M.; Zhang, Z. Fairness and Efficiency Considerations in Performance-Based, Cross-Asset Resource Allocation. J. Transp. Res. Rec. 2016, 19-27. [CrossRef]

41. Laumet, P.; Bruun, M. Trade-off analysis for infrastructure management: new approaches to cross-asset challenges. In Proceedings of the 6th Transport Research Arena, Warsaw, Poland, 18-21 April 2016; pp. 422-429.

42. Lwambuka, L.; Mtenga, P. V Bridge Management Strategy Based on Extreme User Costs for Bridge Network Condition. Adv. Civ. Eng. 2014, 2014, 390359. [CrossRef]

43. France-Mensah, J.; O'Brien, W.J. Budget Allocation Models for Pavement Maintenance and Rehabilitation: Comparative Case Study. J. Manag. Eng. 2018, 24, 05018002. [CrossRef]

44. Farran, M.; Zayed, T. Fitness-oriented multi-objective optimisation for infrastructures rehabilitations. Struct. Infrastruct. Eng. 2015, 11, 1-15. [CrossRef]

45. Denysiuk, R.; Moreira, A.V.; Matos, J.C.; Oliveira, J.R.M.; Santos, A. Two-Stage Multiobjective Optimization of Maintenance Scheduling for Pavements. J. Infrastruct. Syst. 2017, 23, 04017001. [CrossRef]

46. Chen, L.; Raith, A.; Henning, T.F.P. Multi-Objective Optimisation in Decision Making of Road Maintenance. In Proceedings of the Joint NZSA+ORSNZ Conference, Wellington, New Zealand, 24-26 November 2014; p. 125.

47. Irfan Rifai, A.; Hadiwardoyo, S.P.; Gomes Correia, A.; Pereira, P. Genetic Algorithm Applied for Optimization of Pavement Maintenance under Overload Traffic: Case Study Indonesia National Highway. Appl. Mech. Mater. 2016, 845, 369-378. [CrossRef]

48. Santos, J.; Ferreira, A.; Flintsch, G. An adaptive hybrid genetic algorithm for pavement management. Int. J. Pavement Eng. 2019, 20, 266-286. [CrossRef] 
49. Marzouk, M.; Osama, A. Fuzzy-Based Methodology for Integrated Infrastructure Asset Management. Int. J. Comput. Intell. Syst. 2017, 10, 745-759. [CrossRef]

50. Osman, H. Coordination of urban infrastructure reconstruction projects. Struct. Infrastruct. Eng. 2015, 12, 1-14. [CrossRef]

51. Mouratidis, A.; Papageorgiou, G. A rational approach for optimization of road upgrading. Can. J. Civ. Eng. 2010, 37, 1462-1470. [CrossRef]

52. Moteleb, M. Risk Based Decision Making Tools for Sewer Infrastructure Management. Ph.D. Thesis, University of Cincinnati (United States), Cincinnati, OH, USA, 2010.

53. Silver, E.A.; Victor, R.; Vidal, V.; Werra, D. de A tutorial on heuristic methods. Eur. J. Oper. Res. 1980, 5 , 153-162. [CrossRef]

54. Yaseen, S.G.; Al-Slamy, N.M.A. Ant Colony Optimization. Int. J. Comput. Sci. Netw. Secur. 2008, 8, 351-357.

55. Kitaha, A.; Biligiri, K.P. Prioritization-Optimization Process Algorithm to Manage Pavement Networks During the Non-Availability of Historical Data. J. Test. Eval. 2017, 45, 546-563. [CrossRef]

56. Khan, M.U.; Mesbah, M.; Ferreira, L.; Williams, D.J. Development of a post-flood road maintenance strategy: Case study Queensland, Australia. Int. J. Pavement Eng. 2017, 18, 702-713. [CrossRef]

57. Marlow, D.R.; Beale, D.J.; Mashford, J.S. Risk-based prioritization and its application to inspection of valves in the water sector. Reliab. Eng. Syst. Saf. 2012, 100, 67-74. [CrossRef]

58. Salem, O.M.; Miller, R.A.; Deshpande, A.S.; Arurkar, T.P. Multi-criteria decision-making system for selecting an effective plan for bridge rehabilitation. Struct. Infrastruct. Eng. 2013, 9, 806-816. [CrossRef]

59. Abiri-Jahromi, A.; Fotuhi-Firuzabad, M.; Abbasi, E. An efficient mixed-integer linear formulation for long-term overhead lines maintenance scheduling in power distribution systems. IEEE Trans. Power Deliv. 2009, 24, 2043-2053. [CrossRef]

60. Babani, J. Development of an Asset Management Plan for Municipal Water Infrastructure; University of Toronto: Toronto, ON, Canada, 2007.

61. Wang, K.C.P.; Zaniewski, J.P. 20/30 hindsight: the new pavement optimization in the Arizona state highway network. Interfaces (Providence) 1996, 26, 77-89. [CrossRef]

62. Amin, M.S.R.; Amador-Jimenez, L.E. Pavement management with dynamic traffic and artificial neural network: a case study of Montreal. Can. J. Civ. Eng. 2016, 43, 241-251. [CrossRef]

63. Lee, J.; Madanat, S. Optimal policies for greenhouse gas emission minimization under multiple agency budget constraints in pavement management. Transp. Res. Part D Transp. Environ. 2017, 55, 39-50. [CrossRef]

64. Mandiartha, P.; Duffield, C.F.; Razelan, I.S.B.M.; Ismail, A.B.H. Pavement maintenance optimization model using Markov Decision Processes. In Proceedings of the 1st International Conference on Applied and Industrial Mathematics and Statistics, Kuantan, Malaysia, 8-10 August 2017; p. 012104.

65. Fatemeh, N.; Mohamadhossein, N.; Bo, Z.; Kouros, M.A. Optimal Facility-Specific Inspection and Maintenance Decisions under Measurement Uncertainty: Unifying Framework. J. Infrastruct. Syst. 2017, 23, 4017036.

66. Liu, F.; Wang, K. Pavement Performance-Oriented Network Optimization System. Transp. Res. Rec. J. Transp. Res. Board 1996, 1524, 86-93. [CrossRef]

67. Ng, M.; Zhang, Z.; Travis Waller, S. The price of uncertainty in pavement infrastructure management planning: An integer programming approach. Transp. Res. Part C Emerg. Technol. 2011, 19, 1326-1338. [CrossRef]

68. Anastasopoulos, P.; Haddock, J.; Peeta, S. Improving Systemwide Sustainability in Pavement Preservation Programming. J. Transp. Eng. 2014, 140, 4-13. [CrossRef]

69. Adey, B.T.; Herrmann, T.; Tsafatinos, K.; Lüking, J.; Schindele, N.; Hajdin, R. Methodology and base cost models to determine the total benefits of preservation interventions on road sections in Switzerland. Struct. Infrastruct. Eng. 2012, 8, 639-654. [CrossRef]

70. Cafiso, S.; Graziano, A. Di Surrogate Safety Measures for Optimizing Investments in Local Rural Road Networks. Transp. Res. Rec. J. Transp. Res. Board 2011, 2237, 20-30. [CrossRef]

71. Amador-Jiménez, L.E.; Afghari, A.P. Non-monetised multi-objective decision making system for road management. Int. J. Pavement Eng. 2013, 14, 686-696. [CrossRef]

72. Thompson, M.; Sessions, J.; Boston, K.; Skaugset, A.; Tomberlin, D. Forest Road Erosion Control Using Multiobjective Optimization. J. Am. Water Resour. Assoc. 2010, 46, 712-723. [CrossRef] 
73. Attoh-Okine, N.O.; Gibbons, J. Use of belief function in brownfield infrastructure redevelopment decision making. J. Urban Plan. Dev. 2001, 127, 126-143. [CrossRef]

74. Chen, L.; Henning, T.F.P.; Raith, A.; Shamseldin, A.Y. Multi-objective Optimisation for Maintenance Decision Making in Infrastructure Asset Management. J. Manag. Eng. 2015, 31, 04015015. [CrossRef]

75. Liang, S.; Wey, W.M. Resource allocation and uncertainty in transportation infrastructure planning: A study of highway improvement program in Taiwan. Habitat Int. 2013, 39, 128-136. [CrossRef]

76. Lambert, J.; Wu, Y.; You, H.; Clarens, A.; Smith, B. Climate Change Influence on Priority Setting for Transportation Infrastructure Assets. J. Infrastruct. Syst. 2013, 19, 36-46. [CrossRef]

77. Abaza, K.A. Optimal Empirical-Markovian approach for assessment of potential pavement rehabilitation strategies at the project level. Road Mater. Pavement Des. 2018, 19, 646-667. [CrossRef]

78. Orcesi, A.D.; Cremona, C.F. A bridge network maintenance framework for Pareto optimization of stakeholders/users costs. Reliab. Eng. Syst. Saf. 2010, 95, 1230-1243. [CrossRef]

79. Zhang, X.; Gao, H. Road maintenance optimization through a discrete-time semi-Markov decision process. Reliab. Eng. Syst. Saf. 2012, 103, 110-119. [CrossRef]

80. Schmitt, L.M. Theory of genetic algorithms. Theor. Comput. Sci. 2001, 259, 1-61. [CrossRef]

81. Lethanh, N.; Adey, B.T.; Fernando, D.N. Optimal intervention strategies for multiple objects affected by manifest and latent deterioration processes. Struct. Infrastruct. Eng. 2014, 11, 389-401. [CrossRef]

82. Kleiner, Y. Simultaneous Optimization of Pipe and Pavement Renewal Scheduling. In Proceedings of the World Environmental and Water Resources Congress; American Society of Civil Engineers, Cincinnati, $\mathrm{OH}$, USA, 19-23 May 2013; pp. 967-974.

83. Yadollahi, M.; Majid, M.Z.A.; Zin, R.M. Post-Pareto optimality approach to enhance budget allocation process for bridge rehabilitation management. Struct. Infrastruct. Eng. 2015, 11, 1565-1582. [CrossRef]

84. Rolik, O.; Kolesnik, V.; Halushko, D. Decomposition-compensation method of service level management in corporate IT infrastructures with the use of adaptive genetic algorithm. In Proceedings of the 2016 International Conference Radio Electronics \& Info Communications, Kiev, Ukraine, 11-16 September 2016; pp. 1-5.

85. Marzouk, M.; Omar, M. Multiobjective optimisation algorithm for sewer network rehabilitation. Struct. Infrastruct. Eng. 2013, 9, 1094-1102. [CrossRef]

86. Almeida, J.O.; Teixeira, P.F.; Delgado, R.M. Life cycle cost optimisation in highway concrete bridges management. Struct. Infrastruct. Eng. 2013, 10, 1263-1276. [CrossRef]

87. Orcesi, A.D.; Chemineau, H.; Lin, P.-H.; van Gelder, P.; van Erp, N. A risk analysis for asset management considering climate change. In Proceedings of the 6th Transport Research Arena, Warsaw, Poland, 18-21 April 2016; pp. 105-114.

88. Moreira, A.V.; Fwa, T.F.; Oliveira, J.R.M.; Costa, L. Coordination of User and Agency Costs Using Two-Level Approach for Pavement Management Optimization. J. Transp. Res. Rec. 2017, 2639, 110-118. [CrossRef]

89. Fwa, T.F.; Chan, W.T.; Lim, C.T. Decision framework for pavement friction management of airport runways. J. Transp. Eng. 1997, 123, 429-435. [CrossRef]

90. Yang, J.; Lu, J.; Gunaratne, M.; Xiang, Q. Forecasting Overall Pavement Condition with Neural Networks: Application on Florida Highway Network. Transp. Res. Rec. J. Transp. Res. Board 2003, 1853, 3-12. [CrossRef]

91. Torres-Machi, C.; Pellicer, E.; Yepes, V.; Chamorro, A. Towards a sustainable optimization of pavement maintenance programs under budgetary restrictions. J. Clean. Prod. 2017, 148, 90-102. [CrossRef]

92. Yepes, V.; Torres-Machi, C.; Chamorro, A.; Pellicer, E. Optimal pavement maintenance programs based on a hybrid greedy randomized adaptive search procedure algorithm. J. Civ. Eng. Manag. 2016, 22, 540-550. [CrossRef]

93. Lertworawanich, P. Highway network restoration after the great flood in Thailand. Nat. Hazards 2012, 64, 873-886. [CrossRef]

94. Yare, Y.; Venayagamoorthy, G.K.; Aliyu, U.O. Optimal generator maintenance scheduling using a modified discrete PSO. Gener. Transm. Distrib. IET 2008, 2, 834-846. [CrossRef]

95. Zhang, W.; Wang, W. Cost modelling in maintenance strategy optimisation for infrastructure assets with limited data. Reliab. Eng. Syst. Saf. 2014, 130, 33-41. [CrossRef]

96. Abaza, K.; Ashur, S.; Abu-Eisheh, S.; Rabay'a, A. Macroscopic Optimum System for Management of Pavement Rehabilitation. J. Transp. Eng. 2001, 127, 493-500. [CrossRef] 
97. Jorge, D.; Ferreira, A. Road network pavement maintenance optimisation using the HDM-4 pavement performance prediction models. Int. J. Pavement Eng. 2012, 13, 39-51. [CrossRef]

98. Liu, H.; Madanat, S. Adaptive optimisation methods in system-level bridge management. Struct. Infrastruct. Eng. 2014, 11, 884-896. [CrossRef]

99. Gao, H.; Zhang, X. A Markov-Based Road Maintenance Optimization Model Considering User Costs. Comput. Civ. Infrastruct. Eng. 2013, 28, 451-464. [CrossRef]

100. Meneses, S.; Ferreira, A. Pavement maintenance programming considering two objectives: Maintenance costs and user costs. Int. J. Pavement Eng. 2013, 14, 206-221. [CrossRef]

101. Santos, J.; Ferreira, A.; Flintsch, G. A multi-objective optimization-based pavement management decision-support system for enhancing pavement sustainability. J. Clean. Prod. 2017, 164, 1380-1393. [CrossRef]

102. Yang, Y.N.; Kumaraswamy, M.M. Towards life-cycle focused infrastructure maintenance for concrete bridges. Facilities 2011, 29, 577-590. [CrossRef]

103. Orcesi, A.D.; Frangopol, D.M. A stakeholder probability-based optimization approach for cost-effective bridge management under financial constraints. Eng. Struct. 2011, 33, 1439-1449. [CrossRef]

104. Khan, M.U.; Mesbah, M.; Ferreira, L.; Williams, D.J. Development of road deterioration models incorporating flooding for optimum maintenance and rehabilitation strategies. Road Transp. Res. A J. Aust. New Zeal. Res. Pract. 2014, 23, 3-24.

105. Farran, M.; Zayed, T. New life-cycle costing approach for infrastructure rehabilitation. Eng. Constr. Archit. Manag. 2012, 19, 40-60. [CrossRef]

106. Furuta, H.; Frangopol, D.M.; Nakatsu, K. Life-cycle cost of civil infrastructure with emphasis on balancing structural performance and seismic risk of road network. Struct. Infrastruct. Eng. 2011, 7, 65-74. [CrossRef]

107. Yadollahi, M.; Zin, R.M. Multi-strategy budget allocation decision support system for seismic rehabilitation of road infrastructure. Struct. Infrastruct. Eng. 2012, 10, 239-260. [CrossRef]

108. Huang, W.-C.; Teng, J.-Y.; Lin, M.-C. The budget allocation model of public infrastructure projects. J. Mar. Sci. Technol. 2010, 18, 697-708.

109. Miyamoto, A.; Uchino, H. Development of life-cycle cost based budget allocation system for bridge group. In Proceedings of the Life-Cycle Civil Engineering-Proceedings of the 1st International Symposium on Life-Cycle Civil Engineering, Varenna, Italy, 11-14 June 2008; pp. 843-849.

110. Fwa, T.F.; Farhan, J. Optimal multiasset maintenance budget allocation in Highway asset management. J. Transp. Eng. 2012, 138, 1179-1187. [CrossRef]

111. Chou, E.Y.; Wang, S. Benefit Cost Models to Support Pavement Management Decisions; Ohio Department of Transportation: Toledo, Spain, 2012.

112. Bocchini, P.; Frangopol, D.M. Probabilistic bridge network life-cycle connectivity assessment and optimization. In Applications of Statistics and Probability in Civil Engineering; Taylor \& Francis Group: London, UK, 2011; pp. 160-161.

113. Santos, J.; Ferreira, A. Pavement Design Optimization Considering Costs and Preventive Interventions. J. Transp. Eng. 2011, 138, 911-923. [CrossRef]

114. Wu, Z.; Flintsch, G.W. Pavement Preservation Optimization Considering Multiple Objectives and Budget Variability. J. Transp. Eng. 2009, 135, 305-315. [CrossRef]

115. Shoghli, O.; de la Garza, J. Multi-Asset Optimization of Roadways Asset Maintenance. In Proceedings of the ASCE International Workshop on Computing in Civil Engineering, Seattle, WA, USA, 25-27 June 2017; pp. 297-305.

116. Su, Z.; Jamshidi, A.; Núñez, A.; Baldi, S.; De Schutter, B. Multi-level condition-based maintenance planning for railway infrastructures-A scenario-based chance-constrained approach. Transp. Res. Part C Emerg. Technol. 2017, 84, 92-123. [CrossRef]

117. Lin, K.L.; Lin, C.L. Applying Utility Theory to Cost Allocation of Pavement Maintenance and Repair. Int. J. Pavement Res. Technol. 2011, 4, 212-221.

118. Lukas, K.; Borrmann, A.; Rank, E. Using Ant Colony Optimization for Infrastructure Maintenance Scheduling. In Proceedings of the European Conference on Product and Process Modelling; CRC Press: Vienna, Austria, 2010; pp. 371-375.

119. Saha, P.; Liu, R.; Melson, C.; Boyles, S.D. Network Model for Rural Roadway Tolling with Pavement Deterioration and Repair. Comput. Civ. Infrastruct. Eng. 2014, 29, 315-329. [CrossRef] 
120. Tee, K.F.; Li, C.Q. A numerical study of maintenance strategy for concrete structures in marine environment. In Proceedings of the 11th International Conference on Applications of Statistics and Probability in Civil Engineering, Zurich, Switzerland, 1-4 August 2011; pp. 618-625.

121. Jovanovic, S.; Bozovic, D. Optimal Structure and Two Case Study Implementations of a Railway Maintenance Management System. J. Manag. Eng. 2015, 31, 5-14. [CrossRef] 